\title{
Systematic review of membrane components of Gram-positive bacteria responsible as pyrogens for inducing human monocyte/macrophage cytokine release
}

\author{
Christoph Rockel ${ }^{1}$ and Thomas Hartung ${ }^{1,2}$ * \\ Biochemical Pharmacology, University of Konstanz, Konstanz, Germany \\ 2 Department of Environmental Health Sciences, Center for Alternatives to Animal Testing, Bloomberg School of Public Health, The Johns Hopkins University, \\ Baltimore, MD, USA
}

Edited by:

Hani El-Nezami, RMIT-University, Australia

Reviewed by:

Matti Viluksela, National Institute for Health and Welfare, Finland

Silvia Gratz, University of Aberdeen, UK

Jian-Dong Huang, The University of Hong Kong, Hong Kong

*Correspondence:

Thomas Hartung,

Doerenkamp-Zbinden Chair for

Evidence-Based Toxicology,

Bloomberg School of Public Health,

Johns Hopkins University, Baltimore,

MD, USA.

e-mail: thartung@jhsph.edu
Fifty years after the elucidation of lipopolysaccharides (LPS, endotoxin) as the principal structure of Gram-negative bacteria activating the human immune system, its Grampositive counterpart is still under debate. Pyrogen tests based on the human monocyte activation have been validated for LPS detection as an alternative to the rabbit test and, increasingly, the limulus amebocyte lysate test. For full replacement, international validations with non-endotoxin pyrogens are in preparation. Following evidence-based medicine approaches, a systematic review of existing evidence as to the structural nature of the Gram-positive pyrogen was undertaken. For the three major constituents suggested, i.e., peptidoglycan, lipoteichoic acids (LTA), and bacterial lipoproteins (LP), the questions to be answered and a search strategy for relevant literature was developed, starting in MedLine. The evaluation was based on the Koch-Dale criteria for a mediator of an effect. A total of 380 articles for peptidoglycan, 391 for LP, and 285 for LTA were retrieved of which 12,8 , and 24, respectively, fulfilled inclusion criteria. The compiled data suggest that for peptidoglycan two Koch-Dale criteria are fulfilled, four for LTA, and two for bacterial LP. In conclusion, based on the best currently available evidence, LTA is the only substance that fulfills all criteria. LTA has been isolated from a large number of bacteria, results in cytokine release patterns inducible also with synthetic LTA. Reduction in bacterial cytokine induction with an inhibitor for LTA was shown. However, this systematic review cannot exclude the possibility that other stimulatory compounds complement or substitute for LTA in being the counterpart to LPS in some Gram-positive bacteria.

\section{INTRODUCTION}

Bacterial contaminations pose a risk for patients when injected or present on medical implants. The traditional rabbit pyrogen test introduced in the 1940s, in large part, has been replaced by the limulus amebocyte lysate test (LAL, also known as bacterial endotoxin test, BET). Shortcomings of both tests have been discussed elsewhere (Hartung et al., 2001; Schindler et al., 2009). A number of tests based on the human fever reaction have been assessed in two international validation studies (Hoffmann et al., 2005; Schindler et al., 2006). Four tests have been considered validated for the detection of LPS in the respective peer-reviews by the European, US, and Japanese validation bodies and have been formally accepted by European Pharmacopeia and the US Food and Drug Administration. The validated tests are the human whole blood test measuring IL-1 $1 \beta$, ist variant using cryopreserved whole blood, the peripheral blood mononuclear cell (PBMC) test measuring IL-6 and the MonoMac- 6 cell line measuring IL-6. They are commonly referred to now as monocyte activation tests (MAT). The limited database from the validation studies as to non-LPS pyrogens did not, however, allow considering them validated as full replacement for the rabbit test, pointing to the need for novel validation efforts. For these studies it is necessary to understand the structural nature of Gram-positive pyrogens.

The scientific literature on Gram-negative lipopolysaccharides (LPS) includes about 50,000 Medline-listed articles. Grampositive bacteria are by no mean less important, either clinically or as pyrogens, but neither has a structural counterpart for the induction of inflammatory reactions such as cytokine release by macrophages been unambiguously identified nor made available to give rise to similar scientific literature. At the same time, our understanding of recognition mechanisms is continuously expanding (Triantafilou et al., 2002; Draing et al., 2008b; Bauer and Müller, 2009; Beutler, 2009; Kumar et al., 2009).

The extent of scientific publications in many areas has made it very difficult to follow a given topic. One possible method to manage this overwhelming literature is meta-analysis, which follows well defined rules and represents a possibility means of condensing our current state of knowledge from the existing literature. Systematic reviews with meta-analysis of compiled evidence are the principal approach of evidence-based medicine (EBM). Systematic reviews have to be distinguished from the more common narrative reviews in the life sciences: a systematic review answers 
a very narrow set of precisely defined questions. The strategies for identifying relevant evidence (typically by a decision tree) and how to qualify, include, exclude, compile, and interpret this evidence are predefined and reviewed. The result is expressed, if possible, with a measure of uncertainty. Neugebauer and Holaday (1993) first showed that such EBM approaches can be translated from clinical studies to animal and in vitro findings.

The advantages and shortcomings of systematic reviews have been widely discussed (Carr, 1989; Chalmers, 1989; Green, 1989; Neugebauer and Lorenz, 1989; Oettinger, 1989). It is probable that the application of a tree of yes/no decisions raises new faults, and the preference to use methodological criteria for the selection of publications will lead to the simple result that the most actual methods deliver the most accurate data. Construction of a decision tree starts from a subjective point of view and may not necessarily be correct. In spite of such limitations, systematic reviews and meta-analysis appear to represent the most appropriate methods to date for extracting the current state of art from the literature.

Here, the approach of a systematic review was taken to compile current best evidence for a causal role of peptidoglycan, lipoteichoic acids (LTA), and LP as inducers of human monocyte/macrophage inflammatory cytokine release, i.e., also as human pyrogens.

\section{AIM}

Different structures of the Gram-positive cell wall have been proposed as inducers of cytokine release (pyrogens) in human monocyte/macrophages. In a systematic review adopting principles of EBM, the fulfillment of Koch-Dale (K/D) postulates was evaluated for the three most prominent candidate inducers of cytokine release LTA, lipoproteins (LP), and peptidoglycan (PGN). To exclude a species discrepancy between the recognition of bacterial cell wall components in human or animals, only articles on primary human monocytes/macrophages and derived cell lines were used.

Dale adapted the Koch criteria of one cause-one disease to chemical factors as early as 1929 (Dale, 1929). Koch-Dale criteria adapted to the relevant question are:

1. Evidence for presence of LTA, PGN, or LP in cytokine-inducing bacteria

2. Synthesis inhibition of LTA, PGN, or LP impairs cytokine induction

3. Exposure to isolated LTA, PGN, or LP induces cytokine induction

4. Blocking of LTA, PGN, or LP by antibodies or antagonists prevents or reduces cytokine induction

\section{K/D CRITERION 1}

\section{DATABASE FOR K/D CRITERION 1}

First, it was important to verify whether the three analyzed surface molecules were found in or even purified from cytokine-inducing Gram-positive bacteria. PGN is well known to be ubiquitous in Gram-positive bacteria (Vollmer and Holtje, 2004), whereas some Gram-positive bacteria lack LTA, i.e., several Micrococci (M. luteus, M. flavus, M. sodonensis), Bifidobacterium bifidum and
Mycobacteria (Owen and Salton, 1975; Sutcliffe and Shaw, 1991). Bacterial LP are also essential for Gram-positive bacteria (Beveridge, 1999; Navarre and Schneewind, 1999), but we searched systematically information about isolation of these structures (Table 3). For K/D criterion 1 we therefore focused on identifying publications that isolated LTA from Gram-positive bacteria. Using the keywords "isolation lipoteichoic acid Gram-positive bacteria," we identified 179 publications from the library of the U.S. National Library of Medicine and the National Institutes of Health (NCBI). All publications were collected in full length; their abstracts, key words, headlines, and authors were stored as a data file. These reports were screened also for information on bacteria lacking LTA; a secondary search was undertaken to identify for these specific bacteria reports on cytokine induction (or the lack thereof), as well as other specific cytokine-inducing cell wall components reported for these bacteria.

\section{SELECTION OF THE LITERATURE FOR K/D CRITERION 1}

To identify the publications that isolated LTA, the pool of publications was preselected according to decision tree 1 (Figure 1) and was constructed with the following demands:

\section{Original article on isolation of LTA}

Only original articles that were able to isolate LTA confirmed by structural analysis were included; articles reporting only the use of commercial LTA preparations were excluded and reviews were not taken into account, nor were publications that did not reveal detailed information about the isolation procedure of LTA.

\section{Methods appropriate}

Appropriate methods were hot or cold phenol extraction with subsequent gel chromatography, chloroform-methanol, or butanol extraction, hydrophobic interaction chromatography (HIC) and ion-exchange chromatography for purification.

The two criteria led to 58 articles out of 179 publications and are listed in Table 1.

\section{K/D CRITERION 2}

\section{DATABASE FOR K/D CRITERION 2}

The identification of literature on inhibition or even deletion of the synthesis of one of the surface molecules and the respective effect on cytokine induction by the bacteria was the scope for $\mathrm{K} / \mathrm{D}$ criterion 2. Thus, deletion mutants of Gram-positive bacteria for LTA or LP were searched for; PGN was excluded in this case being the main component of the Gram-positive cell wall and a

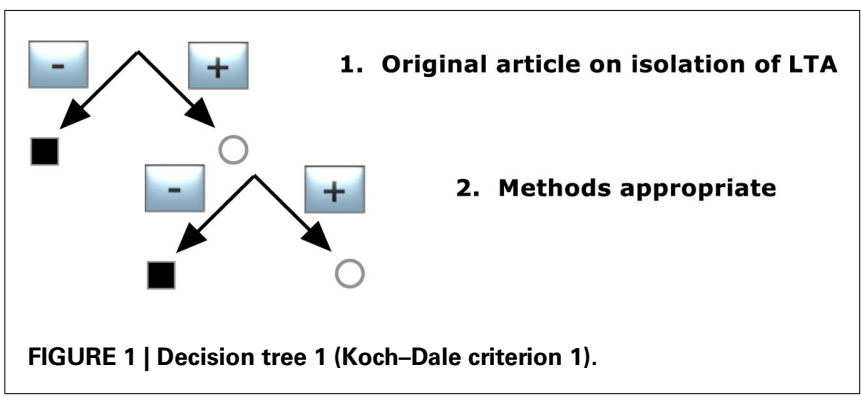


Table 1 | List of publications for isolation of LTA after application of decision tree 1.

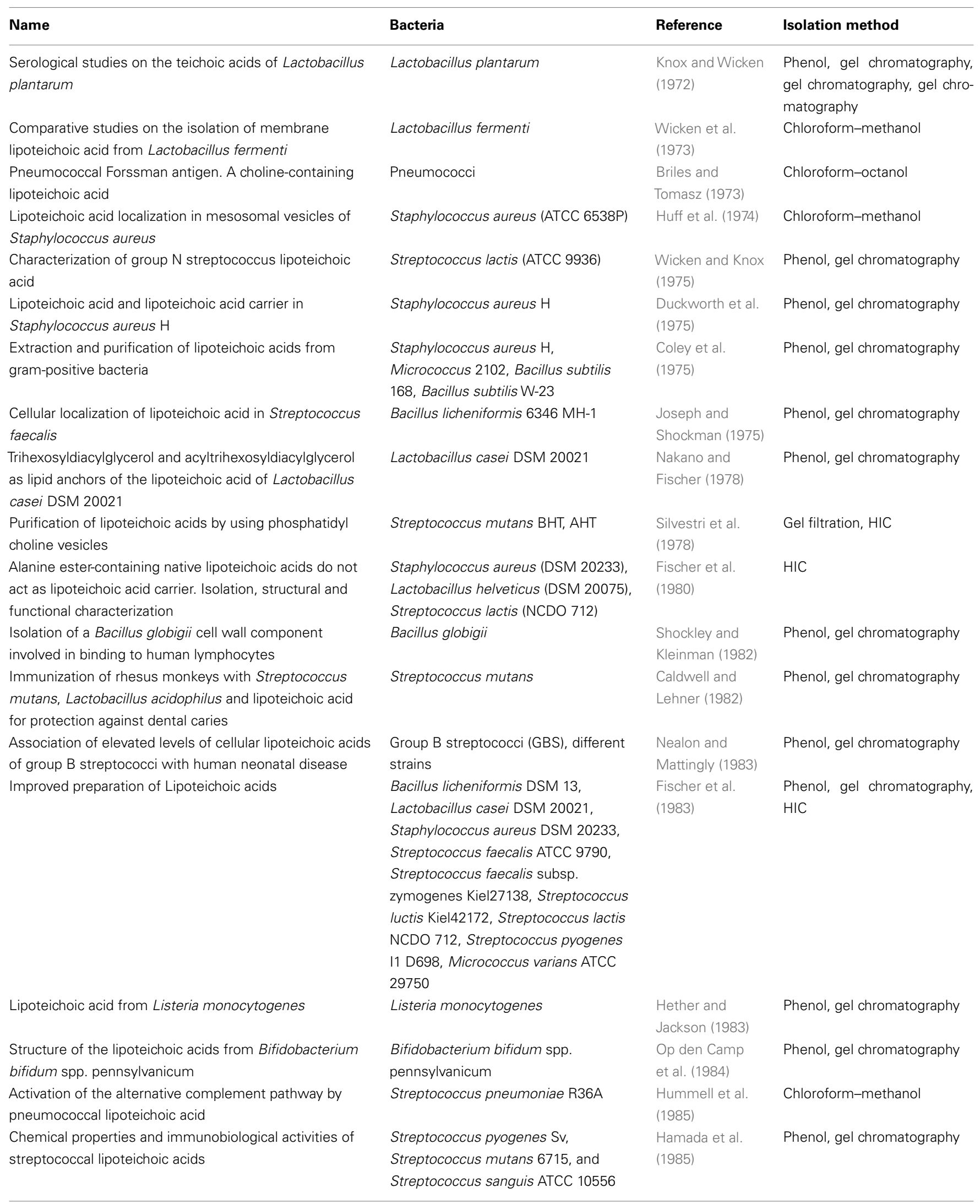


Table 1 | Continued

Name
Comparative studies of lipoteichoic acids from several
Bacillus strains
Lipoteichoic acids in Lactobacillus strains that colonize
the mouse gastric epithelium

Structural studies on lipoteichoic acids from four Listeria strains

Structural studies of a teichoic acid from Streptococcus agalactiae type III

Lipoteichoic acid from Bacillus subtilis subsp. niger WM: isolation and effects on cell wall autolysis and turnover Mediation of Staphylococcus saprophyticus adherence to uroepithelial cells by lipoteichoic acid

"Lipoteichoic acid" of Bifidobacterium bifidum subspecies pennsylvanicum DSM 20239. A lipoglycan with monoglycerophosphate side chains

Stimulation of human monocyte chemiluminescence by staphylococcal lipoteichoic acid

Structure and glycosylation of lipoteichoic acids in Bacillus strains

Distribution analyses of chain substituents of lipoteichoic acids by chemical degradation

Occurrence and structure of lipoteichoic acids in the genus Staphylococcus

On the basic structure of poly(glycerophosphate) lipoteichoic acids

Structure of macroamphiphiles from several Bifidobacterium strains

Isolation and characterization of lipoteichoic acid, a cell envelope component involved in preventing phage adsorption, from Lactococcus lactis subsp. cremoris SK110

Molecular analysis of lipoteichoic acid from Streptococcus agalactiae

\section{Bacteria}

Bacillus subtilis, Bacillus licheniformis, Bacillus pumilus, Bacillus coagulans,

Bacillus megaterium

Lactobacillus fermentum, Lactobacillus leichmannii, Lactobacillus reuteri, Lactobacillus acidophilus, Lactobacillus murinus

Listeria monocytogenes

Streptococcus agalactiae type III

Bacillus subtilis subsp. niger WM

Staphylococcus saprophyticus

Bifidobacterium bifidum subsp. pennsylvanicum DSM 20239

Staphylococcus saprophyticus strains S1 and S35

Bacillus cereus (4 strains), Bacillus subtilis (5 strains), Bacillus licheniformis (1 strain), Bacillus polymyxa (2 strains), and Bacillus circulans (3 strains)

Lactococcus lactis Kiel 48337

Staphylococcus aureus, S. capitis DSM 20326, S. carnosus DSM 20501, S. epidermidis DSM 20044, S. hemolyticus DSM 20263, S. saccharolyticus DSM 20359, S. sciuri DSM 20352, S. warneri DSM 20316, S. cohnii DSM 20260, S. hominis DSM 20328, S. saprophyticus DSM 20229, S. simulans DSM 20322

24 Gram-positive bacteria of the genera Bacillus, Enterococcus, Lactobacillus, Lactococcus, Listeria, Staphylococcus, and the streptococcal pyogenic and oral group Bifidobacterium bifidum YIT 4007 and YIT 4013, Bifidobacterium breve YIT 4010 and YIT 4014, and Bifidobacterium longum YIT 4021

Lactococcus lactis subsp. cremoris SK110

S. pyogenes 147, S. mutans GS-5, Enterococcus hirae ATCC 9790, S. agalactiae 110 ,

\section{Reference \\ Isolation method}

Iwasaki et al. (1986)

Phenol, gel chromatography

Sherman and

Savage (1986)

$$
\text { . }
$$

Uchikawa et al. (1986)

Erbing et al. (1986)

Meyer and

Wouters (1987)

Teti et al. (1987)

Fischer (1987)

Ohshima et al. (1988)

Iwasaki et al. (1989)

Schurek and

Fischer (1989)

Ruhland and

Fiedler (1990)

Fischer et al.

(1990)

Iwasaki et al. (1990)

Sijtsma et al. (1990)

Maurer and Mattingly (1991)
Phenol, gel chromatography

Phenol, gel chromatography

Phenol, gel chromatography

Phenol, gel chromatography

Phenol, gel chromatography

Phenol, gel chromatography

Phenol, gel chromatography

Phenol, gel chromatography

Phenol, gel chromatography

Phenol, gel chromatography

Phenol, HIC

Phenol, gel chromatography

\section{Chloroform-methanol}

Phenol, gel chromatography
(Continued) 
Table 1 | Continued

Name
Separation of the poly(glycerophosphate) lipoteichoic
acids of Enterococcus faecalis Kiel 27738, Enterococcus
hirae ATCC 9790, and Leuconostoc mesenteroides DSM
20343 into molecular species by affinity chromatography
on concanavalin A
Small and medium-angle X-ray analysis of bacterial
lipoteichoic acid phase structure

Hydrophobic interaction chromatography fractionates lipoteichoic acid according to the size of the hydrophilic chain: a comparative study with anion-exchange and affinity chromatography for suitability in species analysis d-Alanyl-lipoteichoic acid in Lactobacillus casei: secretion of vesicles in response to benzylpenicillin Molecular analysis of lipid macroamphiphiles by hydrophobic interaction chromatography, exemplified with lipoteichoic acids

The structure of pneumococcal lipoteichoic acid. Improved preparation, chemical, and mass spectrometric studies Isomalto-oligosaccharide-containing lipoteichoic acid of Streptococcus sanguis. Basic structure Chemiluminescence of human polymorphonuclear leukocytes after stimulation with whole cells and cell wall components of Staphylococcus epidermidis

Competitive binding of calcium and magnesium to streptococcal lipoteichoic acid

Lipoteichoic acid inhibits remineralization of artificial subsurface lesions and surface-softened enamel Cytokine-inducing glycolipids in the lipoteichoic acid fraction from Enterococcus hirae ATCC 9790

A lipoteichoic acid fraction of Enterococcus hirae activates cultured human monocytic cells via a CD14-independent pathway to promote cytokine production, and the activity is inhibited by serum components Structure-function relationship of cytokine induction by lipoteichoic acid from Staphylococcus aureus

Production of IL-12 and IL-18 in human dendritic cells upon infection by Listeria monocytogenes

Characterization of lipoteichoic acids as Lactobacillus delbrueckii phage receptor components

Monoacyl lipoteichoic acid from pneumococci stimulates human cells but not mouse cell

Highly purified lipoteichoic acid from gram-positive bacteria induces in vitro blood-brain barrier disruption through glia activation: role of pro-inflammatory cytokines and nitric oxide

Comparison of lipoteichoic acid from different serotypes of Streptococcus pneumoniae

\section{Bacteria}

Enterococcus faecalis Kiel27738, Enterococcus hirae ATCC 9790, and Leuconostoc mesenteroides DSM 20343

Bifidobacterium bifidum DSM 20239, Enterococcus hirae (Streptococcus faecium) ATCC 9790, Lactococcus garvieae NCDO 2155, Listeria welshimeri SLCC 5354, and S. aureus DSM 20233

Enterococcus faecalis Kiel 27738 (DSM 20371)

Lactobacillus casei ATCC 7469

Enterococcus hirae NICB 8191, Lactococcus garvieae NCFB 2730 , Staphylococcus aureus

Streptococcus pneumoniae R6

Streptococcus sanguis DSM 20567

and of DSM 20068

Staphylococcus epidermidis

Streptococcus sanguis

Lactobacillus casei

Enterococcus hirae ATCC 9790

Enterococcus hirae (ATCC 9790)

S. aureus DSM 20233

L. monocytogenes EGD

Lactobacillus delbrueckii

Streptococcus pneumoniae (strain R36A)

S. aureus DSM 20233

S. pneumoniae strain R6, S. pneumoniae strain Fp23 (serotype 4)

\section{Reference}

Leopold and

Fischer (1991)

Labischinski

et al. (1991)

Leopold and

Fischer (1992)

Pollack et al. (1992)

Fischer (1993)

Behr et al.

(1992)

Kochanowski

et al. (1993)

Martinez-

Martinez et al. (1993)

Rose and

Hogg (1995)

Damen et al.

(1995)

Suda et al.

(1995)

Arakaki et al.

(1998)

Morath et al.

(2001)

Kolb-Maurer

et al. (2003)

Raisanen et al. (2004)

Kim et al.

(2005)

Boveri et al.

(2006)

Draing et al.

(2006)
Phenol, gel chromatography, HIC

\section{Isolation method}

Phenol, gel chromatography, $\mathrm{HIC}$

Phenol, gel chromatography, $\mathrm{HIC}$

Phenol, gel chromatography

Phenol, gel chromatography, $\mathrm{HIC}$

Chloroform-methanol

Phenol, gel chromatography, $\mathrm{HIC}$

Phenol, gel chromatography

Phenol, gel chromatography, $\mathrm{HIC}$

Phenol, gel chromatography

Chloroform-methanol

Phenol, HIC

Butanol-HIC

Phenol, gel chromatography

Phenol, gel chromatography

Phenol, gel chromatography, ion-exchange chromatography Butanol-HIC

Butanol-HIC 
Table 1 | Continued

\begin{tabular}{|c|c|c|c|}
\hline Name & Bacteria & Reference & Isolation method \\
\hline $\begin{array}{l}\text { Opsonic antibodies to Enterococcus faecalis strain } 12030 \\
\text { are directed against lipoteichoic acid }\end{array}$ & Enterococcus faecalis strain 12030 & $\begin{array}{l}\text { Theilacker et al. } \\
\text { (2006) }\end{array}$ & Butanol-HIC \\
\hline $\begin{array}{l}\text { Butanol-extracted lipoteichoic acid induces in vivo } \\
\text { leukocyte adhesion }\end{array}$ & S. aureus DSM 20233 & $\begin{array}{l}\text { Finney et al. } \\
\text { (2007) }\end{array}$ & Butanol-HIC \\
\hline $\begin{array}{l}\text { Lipoteichoic acid isolated from Lactobacillus plantarum } \\
\text { inhibits lipopolysaccharide-induced TNF-alpha production } \\
\text { in THP-1 cells and endotoxin shock in mice }\end{array}$ & L. plantarum K8 (КСТC10887BP) & Kim et al. (2008) & Butanol-HIC \\
\hline $\begin{array}{l}\text { Macroamphiphilic components of thermophilic } \\
\text { actinomycetes: identification of lipoteichoic acid in } \\
\text { Thermobifida fusca }\end{array}$ & $\begin{array}{l}\text { Thermobifida fusca and Rubrobacter } \\
\text { xylanophilus }\end{array}$ & $\begin{array}{l}\text { Rahman et al. } \\
\text { (2009b) }\end{array}$ & Butanol-HIC \\
\hline $\begin{array}{l}\text { Differential immunostimulatory effects of Gram-positive } \\
\text { bacteria due to their lipoteichoic acids }\end{array}$ & $\begin{array}{l}\text { Staphylococcus aureus, Lactobacillus } \\
\text { plantarum, Bacillus subtilis }\end{array}$ & Ryu et al. (2009) & Butanol-HIC \\
\hline $\begin{array}{l}\text { Phenotypic variation in Streptomyces sp. DSM 40537, a } \\
\text { lipoteichoic acid producing actinomycete }\end{array}$ & Streptomyces sp. DSM 40537 & $\begin{array}{l}\text { Rahman et al. } \\
\text { (2009a) }\end{array}$ & Butanol-HIC \\
\hline
\end{tabular}

\section{$+\quad$ 1. Original article on a deletion mutant of LTA or bacterial lipoproteins, respectively}

$x$

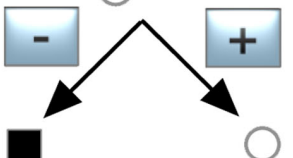

2. Gram-positive bacteria used?

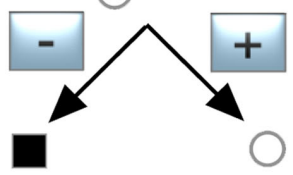

3. Experiments done with human primary cells or cell lines?

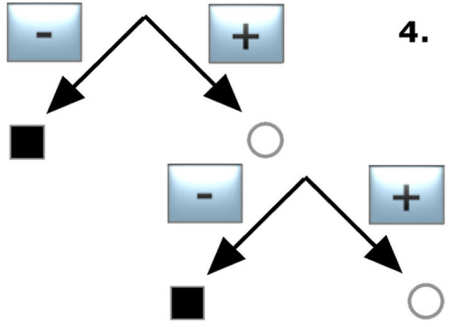

4. Controls appropriate?

FIGURE 2 | Decision tree 2 (Koch-Dale criterion 2).

mutation in complete biosynthesis of PGN would lead to a failure in growth and in surviving of the Gram-positive bacterium. Hence, we used the keywords "(mutation OR deficiency OR deficient) AND bacterial lipoproteins AND cytokines" or "(mutation OR deficiency OR deficient) AND lipoteichoic acid AND cytokines," revealing 62 publications for bacterial lipoproteins and 58 for LTA from NCBI.

\section{VERIFICATION OF K/D CRITERION 2}

To identify publications that give information about a deletion mutant of either LTA or bacterial LP, the pool of publications was selected according to decision tree 2 (Figure 2) and was constructed with the following requirements:
1. Original article on a deletion mutant of LTA or bacterial lipoproteins, respectively

Only original articles were included; abstracts and reviews were excluded.

2. Gram-positive bacteria used?

Publication on Gram-negative bacteria were excluded.

3. Experiments done with human primary cells or cell lines? Only studies with primary human monocytes/macrophages and/or cell lines derived from them were included. Publications reporting only animal experiments and/or animal cells were excluded, and in articles with both human and animal models only the human cell experiments were taken into account for our analysis. 


\section{Controls appropriate?}

The corresponding wildtype should lead to a normal cytokine induction.

5. Significant influence by deletion of LTA or bacterial lipoproteins

Does the mutant lead to an inhibition of cytokine induction?

The demands led to three publications out of 87 (Table 2) for bacterial LP and two for LTA (Table 2).

\section{K/D CRITERIA 3 AND 4}

\section{DATABASE FOR K/D CRITERIA 3 AND 4}

Using the keywords "(bacteria AND lipoteichoic acid) AND cytokines" or "(bacteria AND peptidoglycan) AND cytokines" or "(bacteria AND lipoproteins) AND cytokines" we obtained 285 publications for lipoteichoic acid, 380 publications for peptidoglycan, and 391 publications for lipoproteins from NCBI. All publications were again collected in full length, and pre-selection was done using the following parameters: The pre-selection and database were used for K/D criteria 3 and 4 . Literature cited in these articles constituted a secondary pool of references to complement the systematic analysis.

\section{PRE-SELECTION OF THE LITERATURE FOR K/D CRITERIA 3 AND 4}

In a first step, the pool of publications was preselected according to decision tree 3, as shown in Figure 3. This filter was set to concentrate the data on basic quality standards and was constructed with following demands:

\section{Original article on LTA or PGN or bacterial lipoproteins and cytokines}

Only original articles were included: abstracts and reviews were transferred to pool 2 for background information, as mentioned before.

2. Maximum age of the article must be 10 years

The scientific understanding about pattern recognition molecules (pathogen-associated molecular pattern, PAMP) of bacteria and the respective receptors activating the innate immune system has advanced enormously over the last decade, as have technologies for structural analysis and preparation. Namely the identification of Toll-like receptors and the introduction of NMR and mass-spectroscopy for purity as well as exclusion of Gram-negative endotoxin have advanced strongly. We therefore limited the age of the publications to 10 years. The secondary pool of literature formed by the citations in these articles was not restricted by this criterion in order not to lose valuable supporting information still relevant for today's discussion.

3. Experiments done with human primary cells or cell lines? To exclude a species discrepancy between the recognition of bacterial cell wall components in human or animals, only human studies with primary cells and/or cell lines derived from them were considered. Publications reporting only animal experiments and/or animal cells were not included, and in articles with both human and animal models only the human experiments were taken into account for analysis.

4. Number of replicates appropriate?

To ensure that the results of the experiments reported were accurate enough, only studies performed at least in triplicates and in at least three independent experiments were included. For primary cell experiments it was necessary to use at least three different donors.

5. End points appropriate?

The following parameters were accepted: Cytokine release measured by ELISA or FACS, luciferase assay to determine NFKB activation, PCR, and microarray analysis to determine gene activation.

\section{Endotoxin exclusion (for sub analysis)}

To ensure that the Gram-positive cell wall components were not contaminated by endotoxin we flagged studies that reported a method for endotoxin exclusion, such as limulus amebocyte lysate assay, limulus anti-LPS factor (LALF), polymyxin B or other indications for substances without endotoxin content. This criterion did not lead to an exclusion of the publication but was used to analyze whether a possible endotoxin contamination impacts on the results.

Table 2 | Results for Koch-Dale criterion 2 for bacterial lipoproteins and LTA.

\begin{tabular}{|c|c|c|c|c|}
\hline Reference & Bacteria & Mutation & Cytokines & Outcome \\
\hline \multicolumn{5}{|c|}{ BACTERIAL LIPOPROTEINS } \\
\hline Stoll et al. (2005) & Staphylococcus aureus & $\begin{array}{l}\text { Diacylglycerol transferase (lgt) } \\
\text { deletion }\end{array}$ & $\begin{array}{l}\text { IL-6, IL-8, MCP-1, } \\
\text { TNF, IL-10 }\end{array}$ & $\begin{array}{l}\text { S.a. } \Delta \text { lgt attenuated in growth in nutrient } \\
\text { limited medium, induction of cytokines is } \\
\text { reduced }\end{array}$ \\
\hline Wilkinson et al. (2009) & $\begin{array}{l}\text { Mycobacterium } \\
\text { tuberculosis }\end{array}$ & $\begin{array}{l}\text { Mutation in Delta } 19 \text { gene } \\
\text { responsible for the production } \\
\text { of the } 19-\mathrm{kDa} \text { lipoprotein }\end{array}$ & IL-1 $\beta, T N F, I L-12$ & $\begin{array}{l}\text { M.t. } \Delta 19 \text { leads to reduced IL-1 } \beta \text { induction, } \\
\text { but TNF and IL-12 release is unaffected }\end{array}$ \\
\hline Rusch et al. (2007) & $\begin{array}{l}\text { Mycobacterium } \\
\text { tuberculosis }\end{array}$ & $\begin{array}{l}\text { Mutation in Delta } 19 \text { gene } \\
\text { responsible for the production } \\
\text { of the } 19-\mathrm{kDa} \text { lipoprotein }\end{array}$ & IL-1 $\beta$, TNF & $\begin{array}{l}\text { M.t. } \Delta 19 \text { leads to reduced IL-1 } \beta \text { induction, } \\
\text { but TNF release is unaffected }\end{array}$ \\
\hline \multicolumn{5}{|l|}{ LTA } \\
\hline Perea Velez et al. (2007) & Lactobacillus rhamnosus & $\begin{array}{l}\text { Deletion of dlt operon } \\
\text { responsible for LTA alanylation }\end{array}$ & IL-10, TNF & $\begin{array}{l}\text { IL-10 release significantly reduced for } \mathrm{dlt} \\
\text { mutant, TNF unaffected compared to wt }\end{array}$ \\
\hline
\end{tabular}




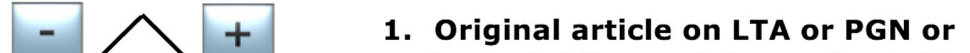 bacterial lipoproteins and cytokines

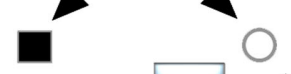

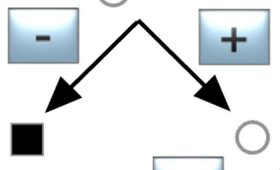 \\ 2. Maximum age of the article must be 10 years

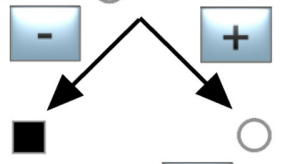 \\ 3. Experiments done with human primary cells or cell lines?

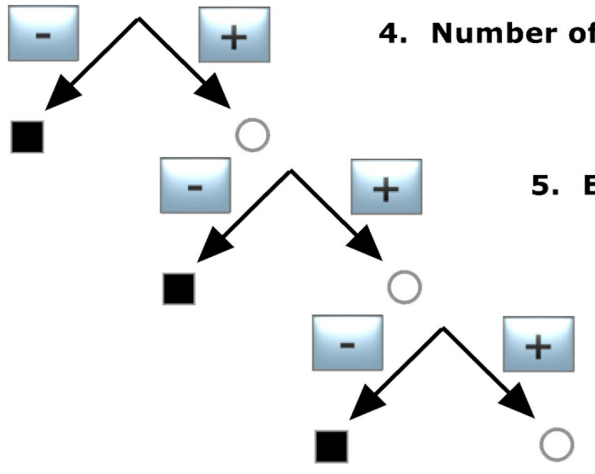 \\ 6. Endotoxin exclusion (Extra point)}

FIGURE 3 | Decision tree 3 (pre-selection of the literature for Koch-Dale criteria 3 and 4).

\section{VERIFICATION OF K/D CRITERION 3 (FIGURE 4)}

1. Determination of cytokine induction after admission of one of the three bacterial surface molecules

Did the applied substance induce cytokine release?

2. Applied substance defined?

The employed PGN, LTA, or lipoprotein had to be specified with respect to purification grade and source.

3. Controls appropriate? In this case, controls in the absence of the investigated molecules should not result in significant cytokine induction.

4. Dose- or concentration-dependent response?

Does the purified material respond in a dose- or concentrationdependent manner, e.g., higher cytokine levels at higher concentrations of the stimulus?

\section{VERIFICATION OF K/D CRITERION 4 (FIGURE 5)}

1. Determination of cytokine induction in the presence of one of the three bacterial surface molecules

Did the applied substance induce significant cytokine release?

2. Exclusion of toxic effects by the antibody or antagonist In this case, the antibody against or antagonist of the three bacterial surface molecules should not have a toxic effect on the cells used.

3. Applied antibody or antagonist defined?

The employed antibody or antagonist had to be specified with respect to purification grade and source.

4. Controls appropriate?

In this case, controls with admission of the antibody or antagonist should not result in significant cytokine induction.
5. Significant change in cytokine release after admission of the antibody or antagonist?

The presence of an antibody or antagonist should lead to a significantly reduced cytokine induction.

If all requirements of the decision trees were fulfilled, then the probability of correct results is high (best evidence). The possible answers were:

Yes - The study demonstrated that the purified and applied substance leads to a significant cytokine-inducing activity in human monocytes/macrophages and can therefore be considered as an immunostimulatory molecule.

No - The substance does not display a sufficient immunostimulatory activity of cytokine induction in human monocytes/macrophages under controlled conditions in the given study.

\section{RESULTS}

PRESENCE OF LTA, BACTERIAL LIPOPROTEINS OR PGN IN GRAM-POSITIVE BACTERIA (K/D CRITERION 1)

Peptidoglycan and bacterial lipoproteins are essential in Grampositive bacteria. PGN has been positively identified and structural variants for many species are known, thereby the criterion is considered fulfilled; in the absence of a structural identification of a general immunostimulatory LP, which is responsible across a wider variety of bacterial species for cytokine induction, only the general presence of LP can be assumed, but the criterion cannot be considered verified. We identified six reports on LP isolation from five bacterial species, largely different in suggested structure, however, 


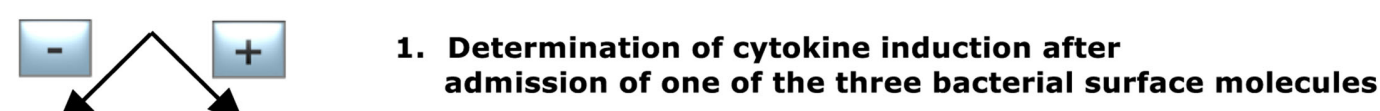

\section{Applied substance defined?}

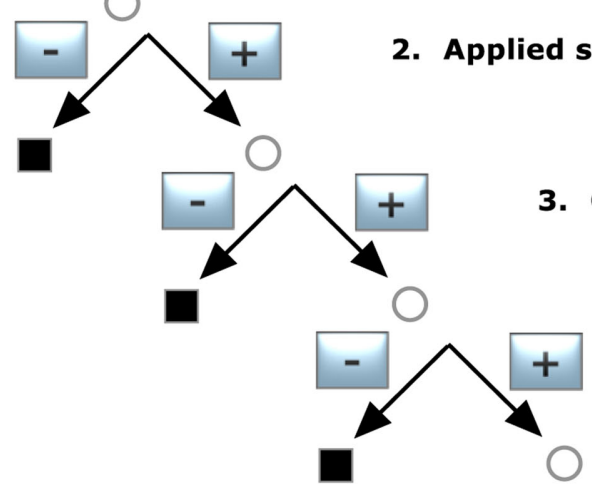

3. Controls appropriate?

FIGURE 4 | Decision tree 4 (Koch-Dale criterion 3).

\section{Correct dose- ore concentration response?}

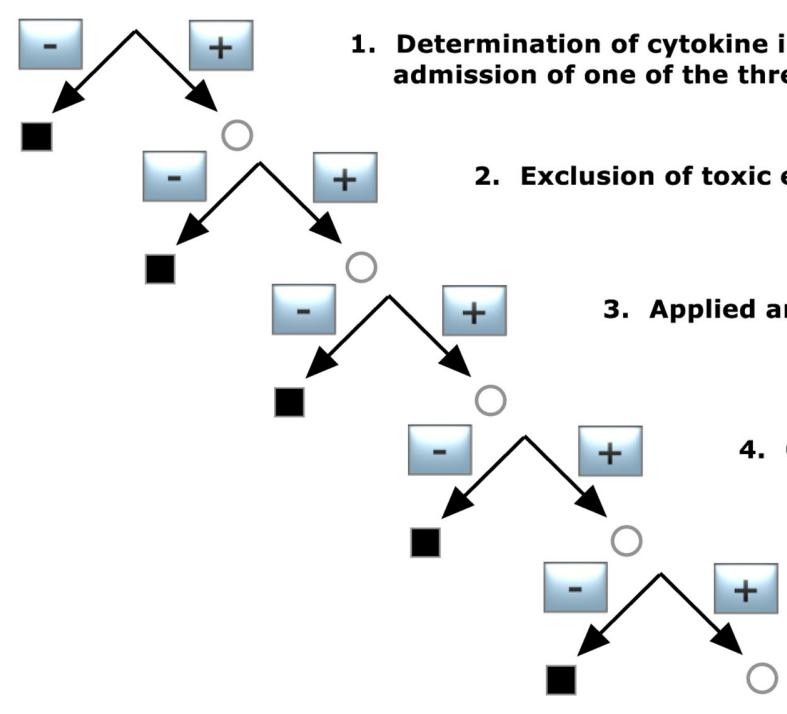

4. Controls appropriate?

FIGURE 5 | Decision tree 5 (Koch-Dale criterion 4).

as presented in Table 3 . The focus was to find publications in which an isolation of LTA was described. Fifty-eight publications showed an isolation of LTA using different purification variants for 81 different bacterial strains, as shown in Table 1. It is therefore concluded that Koch-Dale criterion 1 is fulfilled for PGN and LTA as ubiquitous surface molecules. Given the limitation that it is not known, which LP is responsible for cytokine induction, however, makes it impossible to verify whether the respective specific LP structures are ubiquitous.

\section{DELETION OF GENES INVOLVED IN BIOSYNTHESIS OF LTA, BACTERIAL LIPOPROTEINS, AND PGN IN GRAM-POSITIVE BACTERIA (K/D CRITERION 2)}

The structure of Gram-positive bacterial cell walls consists of a large PGN layer. This layer is mainly responsible for the intact composition of the cell wall that a Gram-positive mutant lacking PGN would be unable to grow and survive. In line with this, there is currently no publication available reporting a mutant free of PGN and its effect on cytokine release; thus the criterion could not be satisfied for PGN.

The references for the deletion of genes involved in biosynthesis of lipoproteins show a decrease in cytokine induction, using a S. aureus mutant (Stoll et al., 2005) and a M. tuberculosis one (Stewart et al., 2005; Wilkinson et al., 2009), as shown in Table 2. For alteration of LTA, we found two publications showing decrease in IL-10 (Perea Velez et al., 2007) and TNF, IL-12, and IFN $\gamma$ (Grangette et al., 2005) release, as shown in Table 2.

These findings show the importance of the two surface molecules, and the K/D criterion 2 can be considered as fulfilled for 
Table 3 | Isolation of different Gram-positive lipoproteins.

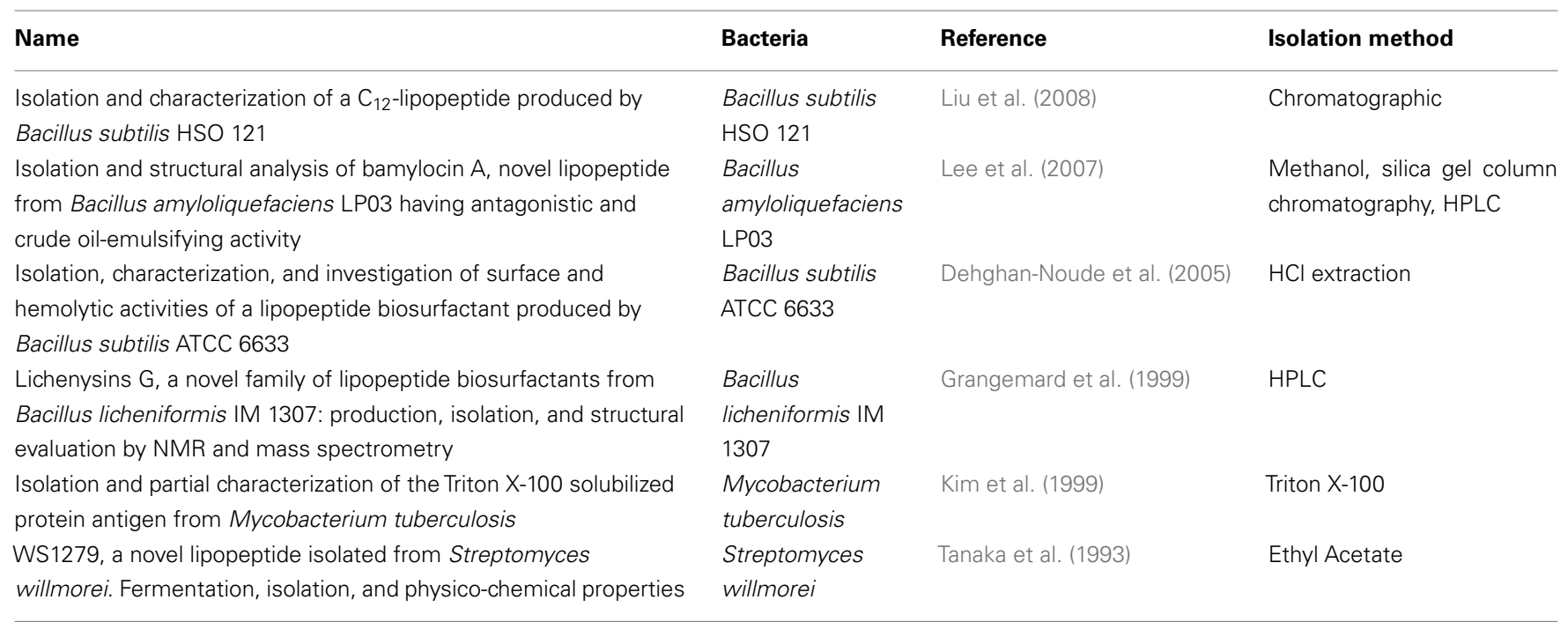

LTA and LP. The lack of evidence for PGN for criterion 2 does not impair a conclusion as to its possible importance as immune stimulus.

\section{CYTOKINE INDUCTION OF LTA, BACTERIAL LIPOPROTEINS, AND PGN IN} GRAM-POSITIVE BACTERIA IN THE HUMAN SYSTEM (K/D CRITERION 3)

Isolation or favorably chemical synthesis of PGN, LTA, and bacterial lipoproteins and their ability to induce cytokine induction in human immune cells was investigated as K/D criterion 3. Publications for lipoproteins were divided in two parts, synthetic lipoproteins such as $\mathrm{Pam}_{3} \mathrm{CysK}$ and isolation, and recombinant lipoproteins. As mentioned above, publications were distinguished between those that provide information about exclusion of endotoxin contamination and that do not provide that information for subanalysis.

\section{Lipoteichoic acid}

Sixteen publications with data for endotoxin exclusion revealed a release of pro-inflammatory cytokines like IL- $1 \beta$, IL-6, IL8, TNF, and G-CSF or the anti-inflammatory cytokine IL-10 in human whole blood, PBMCs, THP-1 cells, human primary monocytes, or neutrophils (Table 4). Additionally, 10 publications without data for exclusion of endotoxin contaminations found, in addition, a release of IL-2 in PBMCs, whereas TNF, IL$1 \beta$, IL-6, IL-8, and IL-10 release was also found in the papers of this non-endotoxin-exclusion group. Since IL-2 is not a monocyte/macrophage product, this result does not add to the conclusions drawn from the higher quality evidence from studies excluding endotoxin contaminations. It is noteworthy, however, that five publications are available describing LTA structures derived by chemical synthesis, excluding endotoxin contamination, showing cytokine induction in human monocytes/macrophages. No publications were retrieved in which isolated or synthesized LTA were not capable of inducing cytokine release in human monocytes/macrophages. It is concluded that there is unambiguous evidence that LTA is capable of activating cytokine release by human monocytes/macrophages.

\section{Peptidoglycan}

If endotoxin-free PGN is used as a stimulus for inducing cytokine release in human immune cells, TNF, IL-1 $\beta$, IL-6, IL-8, IL-10, GMCSF, and RANTES were detected (Table 5). Publications without information about a use of a sufficient endotoxin exclusion revealed similar results, although they mainly used commercially available PGN. However, no synthetic PGN has been reported to induce cytokine release. Furthermore, publications were found in the secondary literature pool showing that further purification of PGN abrogated cytokine induction (Travassos et al., 2004), challenging the capability of PGN to activate monocytes/macrophages. They were excluded here, however, since animal cells were used. Note that several reports showed that the supposed active pattern of PGN, i.e., muropeptides, if free of endotoxin, does not activate cytokine release (for review see Traub et al., 2006). In conclusion, the evidence of PGN inducing cytokine release is limited.

\section{Bacterial lipoproteins}

Isolation and structural analysis of lipoproteins from Grampositive bacteria was done only in a few cases, so we divided retrieved literature into two subgroups, i.e., five reports on synthetic lipoproteins (Table 6) and three reports on recombinant and isolated ones (Table 6). L-OspA from Borrelia burgdorferi is a commercially available recombinant lipoprotein and leads to a release of IL-1 $\beta$, IL-6, IL-10, TNF, and IL-12 in THP-1 cells (DiRita et al., 2000; Giambartolomei et al., 2002). Triton extracted lipoproteins were obtained from Mycoplasma genitalium (Wu et al., 2008). The lipoprotein extracted from $M$. genitalium was used as a stimulus for THP-1 cells and tested for an endotoxin contamination with polymyxin B led to a release of TNF, IL-1 $\beta$, and IL-6.

Synthetic lipoproteins such as $\mathrm{PAM}_{3}$ CysK and $\mathrm{PAM}_{2}$ CysK have biological activity, which is shown as induced release of TNF and IL-6 in publications with data reporting endotoxin exclusion and INF- $\gamma$, IL-12, TNF, IL-8, and IL-6 in non-endotoxin tested $\mathrm{PAM}_{2}$ CysK and $\mathrm{PAM}_{3}$ CysK. In one publication (Greene et al., 2005), MALP-2 leads to a release of IL-6 and IL-8 but it was not tested for endotoxin contamination. 
Table 4 | Publications after fulfillment of decision tree for K/D criterion 3 for LTA.

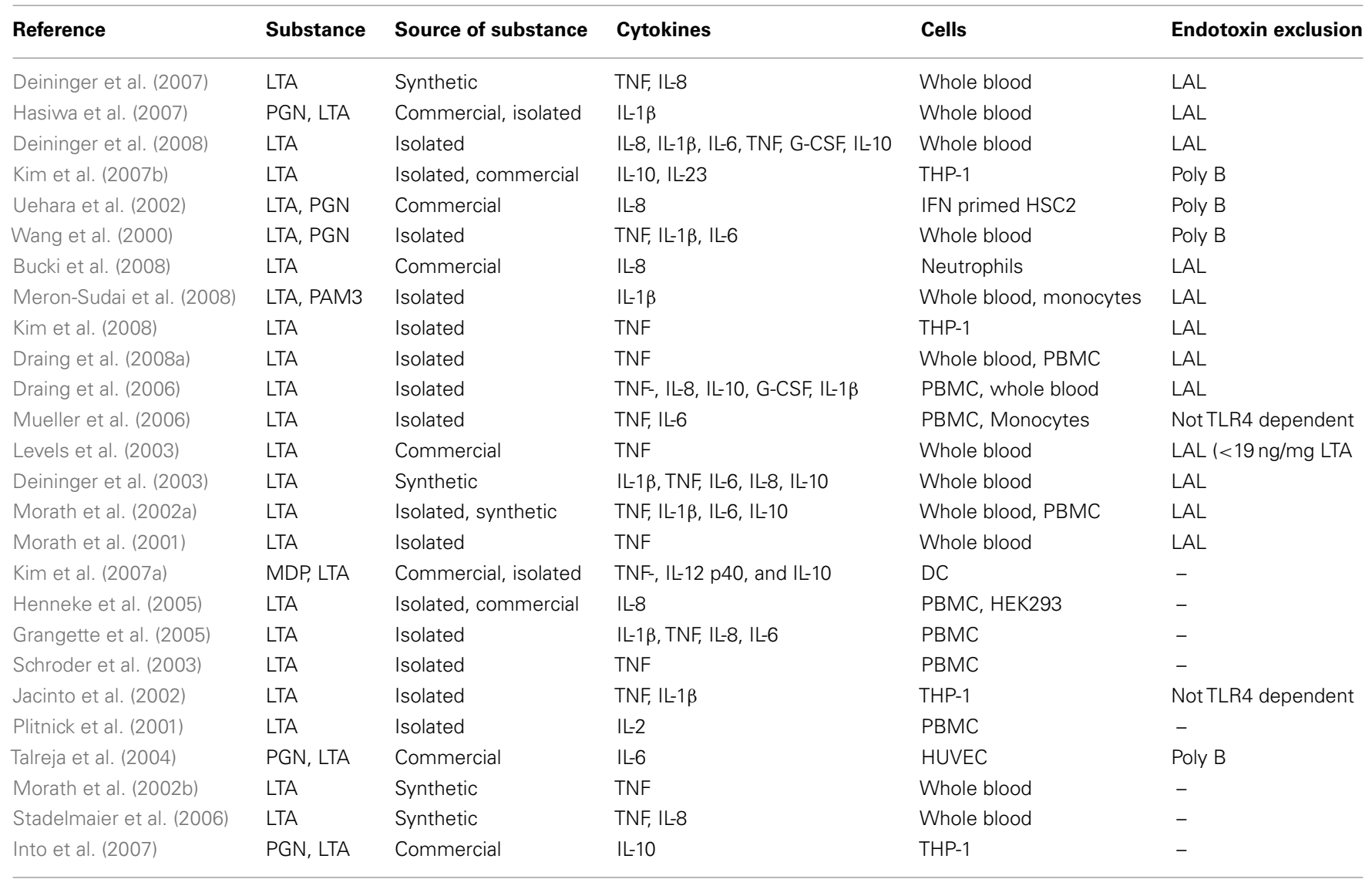

Table 5 | Publications after fulfillment of decision tree for K/D criterion 3 for PGN.

\begin{tabular}{|c|c|c|c|c|c|}
\hline Reference & Substance & Source of substance & Cytokines & Cells & Endotoxin \\
\hline McCurdy et al. (2003) & LP, PGN & Isolated, commercial & IL-1 $\beta$, IL-6, RANTES, GM-CSF & $\begin{array}{l}\text { Cord blood-derived } \\
\text { mast cells (CBMC) }\end{array}$ & $\mathrm{LAL}$ \\
\hline Wang et al. (2000) & LTA, PGN & Isolated & TNF, IL-1 $\beta, I L-6$ & Whole blood & Poly B \\
\hline Langer et al. (2008) & PGN & Isolated & TNF & Whole blood & Poly B \\
\hline Natsuka et al. (2008) & PGN & Isolated & IL-8 & THP-1 & LAL \\
\hline Into et al. (2007) & PGN, LTA & Commercial & $\mathrm{IL}-10$ & THP-1 & - \\
\hline Eriksson et al. (2006) & PGN & Commercial & $\mathrm{IL}-12, \mathrm{IL}-15$ & THP-1 & - \\
\hline Uehara et al. (2006) & PGN & Commercial, isolated & IL-8, MCP-1, IL-6, and TNF & THP-1 & - \\
\hline
\end{tabular}

In conclusion, cytokine induction has been reported for all three substance classes, with only LTA having more than 10 qualifying papers.

BLOCKING OF LTA, BACTERIAL LIPOPROTEINS OR PGN BY ANTIBODIES, ANTAGONISTS, OR INHIBITORS PREVENTS OR REDUCES CYTOKINE RELEASE (K/D CRITERION 4)

Only one study was found for LTA (Draing et al., 2008a) where TNF induction was significantly reduced using polypropylene glycol as an inhibitor for LTA. For PGN, no paper passed the inclusion criteria. A paper from the secondary literature pool was identified describing specific anti-LTA antibodies that augmented recognition of LTA and cytokine response, hinting also at a structure-specific intervention (Mancuso et al., 1994). Thus, there is an evident lack of specific inhibitors and/or studies reporting their effect being applied to block cytokine stimulation, especially for LP and PGN.

\section{DISCUSSION}

This study compiled in a systematic manner the available evidence for the major candidate molecules currently suggested as representing in Gram-positive bacteria the functional counterpart 
Table 6 | Publications after fulfillment of decision tree for K/D criterion 3 for synthetic LP and recombinant or isolated LP.

\begin{tabular}{|c|c|c|c|c|c|}
\hline Reference & Substance & Source of substance & Cytokines & Cells & Endotoxin \\
\hline \multicolumn{6}{|l|}{ SYNTHETIC LP } \\
\hline Wang et al. (2002) & LP & Commercial & TNF, IL-6 & THP-1 & $\mathrm{LAL}$ \\
\hline Schromm et al. (2007) & LP & Isolated & TNF, IL-8 & Monocytes, HEK293 & Poly B \\
\hline McCurdy et al. (2003) & LP, PGN & Isolated, commercial & IL-1, IL-6, RANTES, GM-CSF & $\begin{array}{l}\text { Cord blood-derived } \\
\text { mast cells (CBMC) }\end{array}$ & LAL \\
\hline Schroder et al. (2004) & LP & Commercial & TNF & PBMC & - \\
\hline Sieling et al. (2003) & LP & Commercial & IL-12 p40, GM-CSF, IL-4 & PBMC & - \\
\hline \multicolumn{6}{|c|}{ RECOMBINANT OR ISOLATED LP } \\
\hline Wu et al. (2008) & Mycoplasma LP & Commercial, isolated & TNF, IL-1 $\beta, I L-6$ & THP-1 & Poly B \\
\hline DiRita et al. (2000) & L-OSPA & Commercial, isolated & IL-6, IL-10, IL-12 (p40), TNF, IL-1 $\beta$ & THP-1 & LAL \\
\hline Giambartolomei et al. (2002) & L-OSPA & Commercial, isolated & IL-6, IL-10, and IL-12 & THP-1 & LAL \\
\hline
\end{tabular}

to Gram-negative lipopolysaccharides in innate immune activation such as the pyrogenic reaction. Cytokine induction in human monocytes/macrophages and cell lines derived from these was considered a sufficiently broad key event, for which data are available. The K/D criteria gave a generally accepted framework for the analysis of causation of an effect by a given mediator.

A meta-analysis of the three most commonly considered Grampositive bacterial surface structures involved in immunostimulation and cytokine release was more difficult than anticipated. The number of publications is huge, the information provided is diverse, and the studies offer a variety of different settings, outcomes, and results. Our restriction to human cell studies revealed, on the one hand, more relevant information to the actual interaction between pathogens and the human immune system but, on the other hand, led to a loss of interesting and important pieces of evidence. Often the materials used either were not tested for endotoxin (at least the information about a relevant test was not provided) or commercial preparations were used without giving information about purity and contaminations. Commercial preparations of LTA and PGN have a high risk of being impure or contaminated (Gao et al., 2001; Morath et al., 2002a; Li et al., 2008); there is no reason to assume that this is different for LP. Furthermore, our own experience with PGN and LTA underscores the importance of purity and exclusion of contaminants in the isolated material. In the case of PGN, we could confirm findings of Travassos et al. (2004) that PGN is not able to induce cytokine release in human monocytes when it is highly purified (Rockel et al., 2011). Travassos and his co-workers used a mouse model for investigation of cytokine induction, which led to an exclusion of his studies in this meta-analysis based on the pre-selection criteria.

In some studies, cytokine induction in human cell systems was only a minor aspect of the paper, which led to difficulties in drawing conclusions for our analysis. The main problem was to find studies using antagonists of or antibodies to LTA, PGN, or bacterial lipoproteins, respectively, which leads to a lack of conclusions for the K/D criterion 4 for all structures but LTA. Such studies would help considerably our understanding of the role of LP and PGN. As a possible substitute to provide evidence for K/D criterion 4, reports could be used that show how the blockade or abrogation of specific pattern recognition receptors for the different PAMP impairs cell activation. However, this requires knowledge of these receptors and their specificities as well, as the central problem has been that the predominant techniques used are knock-out-mice, thus restricting us to animal models.

Taken together, our results indicate that among the pertinent candidate molecules under discussion, i.e., LTA, PGN, and bacterial lipoproteins, only for LTA do the retrievable data support all K/D criteria in a satisfactory manner (Table 7). It can therefore be considered as a PAMP, certainly not excluding others. Furthermore, data available are not sufficient to decide if the Gram-positive PAMP can produce endotoxic shock-like reactions. So far, only reports on liver injury in galactosamine-sensitized mice (Hermann et al., 2002) are available (Lehner et al., 2001). It still remains to be elucidated, however, which receptors are involved in this activation and whether and how other PAMP modulate the process. Collecting more data, especially in human cell systems, will provide better information and more knowledge of the interaction between LTA and the human innate immune system.

Furthermore, it will be important to find out if LTA is a prerequisite for cytokine induction using bacteria that have atypical LTAs or even have replaced LTA with other structures. Little is known about these bacteria and their contribution to cytokine release, with the exception of Mycobacteria like M. leprae and M. tuberculosis, where it is suggested that the lipoarabinomannan structures play an important role in cytokine induction (Barnes et al., 1992; Dao et al., 2004). Propionibacteria, Bifidobacteria, and Micrococci have no LTA (Sutcliffe and Shaw, 1991), but no reports were retrieved regarding their cytokine-inducing capacity in human monocytes/macrophages. Finally, strong evidence is available from the fact that synthetic LTA shows a similar cytokine profile compared to the natural isolated substance, which supports the importance of LTA in cytokine induction in humans (Morath et al., 2002b; Deininger et al., 2003).

Bacterial lipoproteins also seem to play a role in cytokine release, but it appears difficult to isolate and purify them. The majority of research is done with synthetic lipoproteins such as $\mathrm{PAM}_{2}$ Cys- $\mathrm{K}_{4}$ or $\mathrm{PAM}_{3}$ Cys- $\mathrm{K}_{4}$, and it remains unclear whether this reflects the stimulation by bacterial components. For the 
Table 7 | Fulfillment of the four K/D criteria for LTA, PGN, and LP (criteria: $1-5$ publications: $+; 6-10$ publications: $++;>10$ publications: +++ ).

\begin{tabular}{llll}
\hline & LTA & PGN & LP \\
\hline K/D 1 & +++ & Ubiquitous & - \\
K/D 2 & + & Not possible & + \\
K/D 3 & +++ & ++ & ++ \\
K/D 4 & + & - & - \\
\hline
\end{tabular}

studies analyzed in this meta-analysis, the outcome is that bacterial lipoproteins only partially fulfill the first three K/D criteria, given that a ubiquitous general structure has not been identified or made available by purification or synthesis; the lack of studies using antibodies or antagonists for these lipoproteins cause it to fail criterion 4.

Peptidoglycan and its contribution as a PAMP, however, is a subject of a long and ongoing discussion with regard to its contribution to cytokine release and interaction with the human immune system. Especially in Gram-positive bacteria, it appeared to be important for detection by the immune system simply because it is a major constituent of the total content of the Grampositive cell wall. PGN was first considered to signal via TLR2 (Schwandner et al., 1999). Nucleotide oligomerization domain (NOD)-like receptors, however (Girardin et al., 2003a,b), recognizes PGN breakdown products. According to more recent studies, PGN has to be internalized and digested for an immune reaction (Wu et al., 2007), and highly purified PGN does not seem to be a trigger for cytokine release (Travassos et al., 2004). However, these reports were not included in our analysis due to the restriction to the human system, and the studies noted were done in mice or in murine cell systems. As mentioned before, our own studies support the findings of Travassos et al. (2004), using human whole blood in this case (Rockel et al., 2011). These results are not included in this analysis, either, as they were not published at the time of literature search.

A key question not addressed in this systematic review, due to the limited number of studies available, is the one of specific activity, i.e., whether the amount of the respective PAMP per bacterium can account for the immunostimulating activity. Until recently, no structure fulfilled this requirement. In contrast to the pg quantities of LPS per ml required, ng per ml quantities of the Gram-positive PAMP are needed. However, Deininger et al. (2008) were able to show that presentation of LTA on a surface augments its stimulatory activity by $3-4 \log$ orders. Similar findings are not available for PGN and LP.

The Koch-Dale criteria are a very common framework to assess the role of mediators for a given biological effect. Alternatively, it is possible to structure an analysis of the role of the three surface molecules in their interaction with the human innate immune system with the criteria described by Bradford Hill for assessing evidence of causation (Hill, 1965):

- Strength: The stronger an association between cause and effect the more likely a causal interpretation, but a small association does not mean that there is not a causal effect.
- Consistency: Consistent findings of different persons in different places with different samples increase the causal role of a factor and its effect.

- Specificity: The more specific an association is between factor and effect, the bigger the probability of a causal relationship.

- Temporality: The effect has to occur after the cause.

- Biological gradient: Greater exposure should lead to greater incidence of the effect with the exception that it can also be inverse, meaning greater exposure leads to lower incidence of the effect.

- Plausibility: A possible mechanism between factor and effect increases the causal relationship, with the limitation that knowledge of the mechanism is limited by best available current knowledge.

- Coherence: A coherence between epidemiological and laboratory findings leads to an increase in the likelihood of this effect. However, the lack of laboratory evidence cannot nullify the epidemiological effect on the associations.

- Experiment: Similar factors that lead to similar effects increase the causal relationship of factor and effect.

Even though Bradford Hill did not intend to describe a checklist, it is here used as a framework to group the data retrieved in the above analysis for the three Gram-positive membrane components LTA, PGN, and LP.

\section{BRADFORD HILL CRITERIA \\ Strength}

The strength of an association between factor and effect was addressed by comparing cytokine induction of the stimulus versus the non-stimulated cells. For LTA, cytokine induction occurred at high induction levels compared to the control, as has been widely described (Table 4), although pure PGN has been reported not to be an immune stimulus (Travassos et al., 2004), and the commonly used commercial peptidoglycan is considered to be contaminated (Li et al., 2008). Even though the strength of evidence is low for the purified component, a role in immune recognition cannot be excluded, as PGN breakdown products such as muramyl dipeptide (MDP) signal intracellularly via NOD (Girardin et al., 2003a,b). For LP it is more difficult to address this question, as there is currently no purified LP from Gram-positive bacteria available. The synthetic derivates $\mathrm{Pam}_{3}$ Cys-SK 4 and $\mathrm{Pam}_{2} \mathrm{Cys}-\mathrm{SK}_{4}$ are potent inducers of cytokine release in cell lines (Buwitt-Beckmann et al., 2005) but fail to induce higher cytokine amounts in complex human systems like PBMCs or human whole blood (Draing et al., 2008a).

\section{Consistency}

Lipoteichoic acids was prepared from many different species by different groups at different places; the database for analysis of cytokine induction by different LTAs is large (Tables 1 and 4). Evidence for LTA is strong, as results are consistent over different places and different experimenters. The findings for PGN not contributing to cytokine release when highly purified (Travassos et al., 2004) represent strong evidence for the absence of a causal relationship in this case. For LP, however, findings may be considered as consistent for different persons and places, but the lack of 
LP preparations from a wide range of species leads to the lack of different reports, as only synthetic derivates are broadly used. It is still not clear whether these synthetic molecules really reflect the natural situation.

\section{Specificity}

A high specificity of the effect would lead to a strong evidence for a causal effect. The readout systems mentioned in this review are based on reactions of the human innate immune system. This system needs to react very quickly to threats and without specificity as the intruder has to be reacted to. Hence, cytokine release in complex human systems is an unspecific reaction. Here it is only possible to draw conclusions based on the cytokine profile of the three cell wall components. LTA induces a broad spectrum of cytokines, different from the spectra of PGN and LP. The widest cytokine pattern is the one from whole bacteria, as they are able to induce the whole range of human cytokines, as expected. It also has been taken into account that synthetic LTA is able to induce cytokines in humans in a similar manner to native LTA (Deininger et al., 2003, 2007), which provides evidence for a specific reaction. Synthetic lipoproteins are also able to induce cytokine induction at least in cell lines (Buwitt-Beckmann et al., 2005). The specificity of reactivity is shown only for LTA so far, using synthetic variants, even defined minimal structures (Deininger et al., 2003, 2007).

\section{Temporality}

As the effect has to occur after the stimulation to provide evidence for a causal effect, it is here possible to fulfill this sub-point for LTA, PGN, and LP as kinetics were reported in some cases for stimulations. We can clearly say that cytokine release always occurs after the stimulation with the three cell wall components.

\section{Biological gradient}

Increase of the stimulus concentration leads in all cases to an increase in cytokine release, independent of whether the stimulus is whole bacteria, LTA (Table 4), or PGN (Table 5). It was also previously shown for synthetic lipoproteins (Buwitt-Beckmann et al., 2005). Concentration-dependent cytokine induction has been reported for all stimuli and therefore supports the evidence of a causal relationship.

\section{Plausibility}

Next it is important to identify a plausible mechanism for the interaction of LTA, PGN, and LP with the human innate immune system, which would provide more evidence for a causal relationship between stimulus and cytokine release. Knowledge of a receptor system of monocytes/macrophages to recognize the relevant structures would represent such plausibility. Historically, LTA was first considered to signal via TLR4 (Takeuchi et al., 1999), but this was found to be due to contaminations with LPS (Morath et al., 2002a). Purified LTA was then considered to signal via TLR2 (Schwandner et al., 1999) with confirmation by using a synthetic LTA (Morath et al., 2002b). This was questioned again by using a LTA from a SA $\Delta$ lgt mutant lacking lipoproteins (Hashimoto et al., 2006) with a decreased cytokine-inducing activity and loss of TLR2 dependence. Our own findings, however, show that this mutant LTA is not able to induce cytokines in cell lines (Bunk et al., 2010) but has normal cytokine-inducing activity in human whole blood (von Aulock et al., 2007). This underlines the importance of Bradford Hill's statement that the knowledge of a mechanism is limited by current knowledge (Hill, 1965). Note that there is a similar controversy for PGN, which was first described to be a TLR2 stimulus (Takeuchi et al., 1999) but later was found not to be immunostimulatory when highly purified (Travassos et al., 2004; Rockel et al., 2011). At least for synthetic lipoproteins the mechanism appears to be signaling via TLR2 (Parker et al., 2004). In addition, it is important to mention that the three surface molecules are widespread and highly conserved in Gram-positive bacteria. The fact that synthetic molecules of LTA and LP display a somehow similar cytokine-inducing activity leads to a prediction of a possible specific mechanism for immune recognition even though these mechanisms are still not fully understood and are somewhat controversial. We can here conclude that the mechanism, and therefore the specificity, is highly dependent on current general knowledge of purification procedures, experimental settings, and ligandreceptor interactions. At least for LTA and lipoproteins, the causal relationship is plausible for being recognized by TLR2, as well as for PGN being recognized intracellularly by NOD molecules.

\section{Coherence}

A coherence between epidemiological and laboratory finding would increase the causal connection between the stimuli and the effect on cytokine release. Gram-positive bacteria are known to have the potential to induce severe infections and sepsis in humans, i.e., diseases associated with cytokine storms. So it is necessary to address here the comparison between the spectrum of cytokine release of whole bacteria and the purified components LTA, PGN, and LP. Whole bacteria induce a wide range of cytokines (Hessle et al., 2005). LTA was similar to this cytokine pattern (Rockel et al., 2011). PGN and LP do not induce a similar number of cytokines in the same human whole blood model (Rockel et al., 2011), which suggests coherence mainly in the case of LTA. Additionally, LTA was found to be detectable in patients with Streptococcus pneumoniae induced meningitis (Stuertz et al., 1998), which leads to a higher probability of evidence for a causal relationship between stimulus and effect. A high coherence between epidemiological and laboratory finding thus only exists for LTA.

Another aspect of coherence is the similarity to the Gramnegative counterpart: The factor most similar to the three surface molecules LTA, PGN, and LP is the Gram-negative molecule LPS. It is often used as a positive control stimulation and possesses a structural similarity as amphiphilic molecule with lipid anchor to LTA and lipoproteins (Schroder et al., 2008). No such similarity exists with PGN.

\section{Experiment}

In experimental systems all structures have been shown to induce cytokine release (see K/D criterion 2). The potency of LTA in cytokine release compared to LPS is about 100- to 1000-fold lower (Kimbrell et al., 2008), but LTA potency is still 100- to 10,000-fold higher than for PGN (Travassos et al., 2004) or LP (Kimbrell et al., 2008). The difference in potency to LPS is abolished when LTA is presented on a surface (Deininger et al., 2008), a phenomenon not observed for other stimuli.

In summary, LTA provides most evidence for a causal relationship of stimulus and effect based on Bradford Hill's criteria, 
as all criteria are fulfilled to some extent. For PGN, four out of eight criteria are fulfilled; the exceptions are strength, specificity, coherence, and experiment. For strength it has to be noted that the weak association here does not mean that there is no causal connection between stimulus and effect, considering that PGN breakdown products are recognized by the immune system. For bacterial lipoproteins only four criteria are fulfilled, namely temporality, biological gradient, plausibility, and experiment, with a weaker evidence for a plausible mechanism as only synthetic lipoproteins are available with a clearly investigated specific mechanism via human TLR2. The experimental response is weak despite structural similarity to LPS, results are consistent but do not come from different studies, and the coherence with regard to the spectrum of cytokines induced is limited. In line with the Koch-Dale criteria, the considerations suggested by Bradford Hill suggest that LTA has a causal role in cytokine release by human monocytes/macrophages inducible by Gram-positive bacteria (Table 8). Finally, it is concluded that bacterial lipoproteins and PGN might play a role in cytokine induction in humans, as no contradictory results were found for human monocytes/macrophages. LTA is the only Gram-positive membrane compound that fulfills all of the four Koch/Dale and all eight of the Bradford Hill Criteria.

This evaluation suggests that LTA is the appropriate reference material for pyrogen testing. However, the fact that potency of

\section{REFERENCES}

Arakaki, R., Sugawara, S., Nakashima, H., Kotani, S., and Takada, H. (1998). A lipoteichoic acid fraction of Enterococcus hirae activates cultured human monocytic cells via a CD14-independent pathway to promote cytokine production, and the activity is inhibited by serum components. FEMS Immunol. Med. Microbiol. 22, 283-291.

Barnes, P. F., Chatterjee, D., Abrams, J. S., Lu, S., Wang, E., Yamamura, M., Brennan, P. J., and Modlin, R. L. (1992). Cytokine production induced by Mycobacterium tuberculosis lipoarabinomannan. Relationship to chemical structure. $J$. Immunol. 149, 541-547.

Bauer, S., and Müller, T. (2009). Pattern recognition in innate immunity. Adv. Exp. Med. Biol. 653, 15-34.

Behr, T., Fischer, W., Peter-Katalinic, J., and Egge, H. (1992). The structure of pneumococcal lipoteichoic acid. Improved preparation, chemical and mass spectrometric studies. Eur. J. Biochem. 207, 1063-1075.

Beutler, B. A. (2009). TLRs and innate immunity. Blood 113, 1399-1407.

Beveridge, T. J. (1999). Structures of gram-negative cell walls and their derived membrane vesicles. $J$. Bacteriol. 181, 4725-4733.

Boveri, M., Kinsner, A., Berezowski, V., Lenfant, A. M., Draing, C., Cecchelli, R., Dehouck, M. P., Hartung, T., Prieto, P., and Bal-Price, A.
(2006). Highly purified lipoteichoic acid from gram-positive bacteria induces in vitro blood-brain barrier disruption through glia activation: role of pro-inflammatory cytokines and nitric oxide. Neuroscience 137, 1193-1209.

Briles, E. B., and Tomasz, A. (1973). Pneumococcal Forssman antigen. A choline-containing lipoteichoic acid. J. Biol. Chem. 248, 6394-6397.

Bucki, R., Byfield, F., Kulakowska, A., McCormick, M. E., Drozdowski, W., Namiot, Z., Hartung, T., and Janmey, P. A. (2008). Extracellular gelsolin binds lipoteichoic acid and modulates cellular response to proinflammatory bacterial wall components. J. Immunol. 181, 4936-4944.

Bunk, S., Sigel, S., Metzdorf, D., Sharif, O., Triantafilou, K., Triantafilou, M., Hartung, T., Knapp, S., and von Aulock, S. (2010). Internalization and coreceptor expression are critical for TLR2-mediated recognition of lipoteichoic acid in human peripheral blood. J. Immunol. 185, 3708-3717.

Buwitt-Beckmann, U., Heine, H., Wiesmuller, K., Jung, G., Brock, R., and Ulmer, A. J. (2005). Lipopeptide structure determines TLR2 dependent cell activation level. FEBS J. 272, 6354-6364.

Caldwell, J., and Lehner, T. (1982). Immunisation of rhesus monkeys with Streptococcus mutans, Lactobacillus acidophilus and lipoteichoic

Table 8 | Fulfillment of Bradford Hill criteria for LTA, PGN, and LP (personal weighing of evidence by the authors as explained in the text).

\begin{tabular}{llll}
\hline & LTA & PGN & LP \\
\hline Strength & +++ & - & - \\
Consistency & +++ & +++ & - \\
Specificity & ++ & - & + \\
Temporality & +++ & +++ & +++ \\
Biological Gradient & +++ & +++ & +++ \\
Plausibility & +++ & + & ++ \\
Coherence & +++ & - & - \\
Experiment & +++ & - & ++ \\
\hline
\end{tabular}

LTA as monocyte activator is only fully exerted, i.e., amplified by about 4 log orders (Deininger et al., 2008) when presented on a surface, requires either the use of very high concentrations of pure LTA or reliance on crude membrane preparations that present LTA appropriately. Future developments might include the coating of (nano-)particles with LTA to establish a pure highly active Grampositive reference material. For current validation efforts, the use of bacterial lysates appears to be advisable, which also safeguards the presence of possible pyrogenic response modifiers other than LTA.

acid for protection against dental caries. J. Med. Microbiol. 15, 339-350.

Carr, D. B. (1989). Causality, predictability and explanation. Theor. Surg. 4, 88-91.

Chalmers, T. C. (1989). The quality of primary and secondary research and meta-analysis. Theor. Surg. 4, 98-100.

Coley, J., Duckworth, M., and Baddiley, J. (1975). Extraction and purification of lipoteichoic acids from Gram-positive bacteria. Carbohydr. Res. 40, 41-52.

Dale, H. H. (1929). Croonian lectures on some chemical factors in the control of the circulation. Lancet 213, 1285-1290.

Damen, J. J., Exterkate, R. A., and ten Cate, J. M. (1995). Lipoteichoic acid inhibits remineralization of artificial subsurface lesions and surfacesoftened enamel. J. Dent. Res. 74, 1689-1694.

Dao, D. N., Kremer, L., Guerardel, Y., Molano, A., Jacobs, W. R. Jr., Porcelli, S. A., and Briken, V. (2004). Mycobacterium tuberculosis lipomannan induces apoptosis and interleukin-12 production in macrophages. Infect. Immun. 72, 2067-2074.

Dehghan-Noude, G., Housaindokht, M., and Bazzaz, B. S. (2005). Isolation, characterization, and investigation of surface and hemolytic activities of a lipopeptide biosurfactant produced by Bacillus subtilis ATCC 6633. J. Microbiol. 43, 272-276.

Deininger, S., Figueroa-Perez, I., Sigel, S., Stadelmaier, A., Schmidt, R. R., Hartung, T., and von Aulock, S. (2007). Use of synthetic derivatives to determine the minimal active structure of cytokineinducing lipoteichoic acid. Clin. Vaccine Immunol. 14, 1629-1633.

Deininger, S., Stadelmaier, A., von Aulock, S., Morath, S., Schmidt, R., and Hartung, T. (2003). Definition of structural prerequisites for lipoteichoic acid-inducible cytokine induction by synthetic derivatives 1 . J. Immunol. 170, 4134-4138.

Deininger, S., Traub, S., Aichele, D., Rupp, T., Baris, T., Möller, H. M., Hartung, T., and von Aulock, S. (2008). Presentation of lipoteichoic acid potentiates its inflammatory activity. Immunobiology 213 , 519-529.

DiRita, V., Murthy, P., Dennis, V., Lasater, B., and Philipp, M. (2000). Interleukin-10 modulates proinflammatory cytokines in the human monocytic cell line THP-1 stimulated with Borrelia burgdorferi lipoproteins. Infect. Immun. 68, 6663-6669.

Draing, C., Pfitzenmaier, M., Zummo, S., Mancuso, G., Geyer, A., Hartung, T., and von Aulock, S. (2006). Comparison of lipoteichoic acid from different serotypes of Streptococcus pneumoniae. J. Biol. Chem. 281, 33849-33859. 
Draing, C., Traub, S., Deininger, S., Mang, P., Möller, H. M., Manso, M., Rossi, F., Morath, S., Hartung, T., and von Aulock, S. (2008a). Polypropylene glycol is a selective binding inhibitor for LTA and other structurally related TLR2 agonists. Eur. J. Immunol. 38, 797-808.

Draing, C., Sigel, S., Deininger, S., Traub, S., Munke, R., Mayer, C., Hareng, L., Hartung, T., von Aulock, S., and Hermann, C. (2008b). Cytokine induction by Gram-positive bacteria. Immunobiology 213, 285-296.

Duckworth, M., Archibald, A. R., and Baddiley, J. (1975). Lipoteichoic acid and lipoteichoic acid carrier in Staphylococcus aureus H. FEBS Lett. 53, 176-179.

Erbing, B., Kenne, L., Lindberg, B., Helting, T., and Hammerschmid, F. (1986). Structural studies of a teichoic acid from Streptococcus agalactiae type III. Carbohydr. Res. 156, 147-155.

Eriksson, M., Meadows, S., Basu, S., Mselle, T. F., Wira, C. R., and Sentman, C. L. (2006). TLRs mediate IFN-production by human uterine NK cells in endometrium. J. Immunol. 177, 6219-6224.

Finney, S. J., Anning, P. B., Cao, T. V., Perretti, M., Evans, T. W., and Burke-Gaffney, A. (2007). Butanol-extracted lipoteichoic acid induces in vivo leukocyte adhesion. Biochem. Biophys. Res. Commun. 364, 831-837.

Fischer, W. (1987). "Lipoteichoic acid" of Bifidobacterium bifidum subspecies pennsylvanicum DSM 20239. A lipoglycan with monoglycerophosphate side chains. Eur. J. Biochem. 165, 639-646.

Fischer, W. (1993). Molecular analysis of lipid macroamphiphiles by hydrophobic interaction chromatography, exemplified with lipoteichoic acids. Anal. Biochem. 208, 49-56.

Fischer, W., Koch, H. U., and Haas, R. (1983). Improved preparation of lipoteichoic acids. Eur. J. Biochem. 133, 523-530.

Fischer, W., Koch, H. U., Rosel, P., and Fiedler, F. (1980). Alanine estercontaining native lipoteichoic acids do not act as lipoteichoic acid carrier. Isolation, structural and functional characterization. J. Biol. Chem. 255, 4557-4562.

Fischer, W., Mannsfeld, T., and Hagen, G. (1990). On the basic structure of poly(glycerophosphate) lipoteichoic acids. Biochem. Cell Biol. 68, 33-43.

Gao, J. J., Xue, Q., Zuvanich, E. G., Haghi, K. R., and Morrison, D. C. (2001). Commercial preparations of lipoteichoic acid contain endotoxin that contributes to activation of mouse macrophages in vitro. Infect. Immun. 69, 751-757.

Giambartolomei, G., Dennis, V., Lasater, B., Murthy, P., and Philipp, M. (2002). Autocrine and exocrine regulation of interleukin-10 production in THP-1 cells stimulated with Borrelia burgdorferi lipoproteins. Infect. Immun. 70, 1881-1888.

Girardin, S., Boneca, I., Carneiro, L., Antignac, A., Jéhanno, M., Viala, J., Tedin, K., Taha, M. K., Labigne, A., Zähringer, U., Coyle, A. J., DiStefano, P. S., Bertin, J., Sansonetti, P. J., and Philpott, D. J. (2003a). Nod1 detects a unique muropeptide from gram-negative bacterial peptidoglycan. Science 300, 1584-1587.

Girardin, S., Boneca, I., Viala, J., Chamaillard, M., Labigne, A., Thomas, G., Philpott, D. J., and Sansonetti, P. J. (2003b). Nod2 is a general sensor of peptidoglycan through muramyl dipeptide (MDP) detection. J. Biol. Chem. 278, 8869-8872.

Grangemard, I., Bonmatin, J. M., Bernillon, J., Das, B. C., and Peypoux, F. (1999). Lichenysins G, a novel family of lipopeptide biosurfactants from Bacillus licheniformis IM 1307: production, isolation and structural evaluation by NMR and mass spectrometry. J. Antibiot. 52, 363-373.

Grangette, C., Nutten, S., Palumbo, E., Morath, S., Hermann, C., Dewulf, J., Pot, B., Hartung, T., Hols, P., and Mercenier, A. (2005). Enhanced antiinflammatory capacity of a $\mathrm{Lac}$ tobacillus plantarum mutant synthesizing modified teichoic acids. Proc. Natl. Acad. Sci. U.S.A. 102, 10321-10326.

Green, J. P. (1989). Association and cause: problems with Koch-Dale criteria. Theor. Surg. 4, 94-98.

Greene, C., Carroll, T., Smith, S., Taggart, C. C., Devaney, J., Griffin, S., O'Neill, S. J., and McElvaney, N. G. (2005). TLR-induced inflammation in cystic fibrosis and noncystic fibrosis airway epithelial cells. J. Immunol. 174, 1638-1646.

Hamada, S., Yamamoto, T., Koga, T., McGhee, J. R., Michalek, S. M., and Yamamoto, S. (1985). Chemical properties and immunobiological activities of streptococcal lipoteichoic acids. Zentralbl. Bakteriol. Mikrobiol. Hyg. A 259, 228-243.

Hartung, T., Aaberge, I., Berthold, S., Carlin, G., Charton, E., Coecke, S., Fennrich, S., Fischer, M., Gommer, M., Halder, M., Haslov, K., Jahnke, M., Montag-Lessing, T., Poole, S., Schechtman, L., Wendel, A., and
Werner-Felmayer, G. (2001). Novel pyrogen tests based on the human fever reaction. The report and recommendations of ECVAM workshop 43. Altern. Lab. Anim. 29, 99-123.

Hashimoto, M., Tawaratsumida, K. Kariya, H., Kiyohara, A., Suda, Y., Krikae, F., Kirikae, T., and Götz, F. (2006). Not lipoteichoic acid but lipoproteins appear to be the dominant immunobiologically active compounds in Staphylococcus aureus. J. Immunol. 177, 31-62.

Hasiwa, M., Kullmann, K., von Aulock, S., Klein, C., and Hartung, T. (2007). An in vitro pyrogen safety test for immune-stimulating components on surfaces. Biomaterials 28, 1367-1375.

Henneke, P., Morath, S., Uematsu, S., Weichert, S., Pfitzenmaier, M. Takeuchi, O., Müller, A., Poyart, C., Akira, S., Berner, R., Teti, G. Geyer, A., Hartung, T., Trieu-Cuot, P., Kasper, D. L., and Golenbock, D. T. (2005). Role of lipoteichoic acid in the phagocyte response to group B streptococcus. J. Immunol. 174 6449-6455.

Hermann, C., Spreitzer, I., Schroder, N. W., Morath, S., Lehner, M. D., Fischer, W., Schütt, C., Schumann, R. R., and Hartung, T. (2002). Cytokine induction by purified lipoteichoic acids from various bacterial species role of LBP, sCD14, CD14 and failure to induce IL-12 and subsequent IFNgamma release. Eur. J. Immunol. 32, 541-551.

Hessle, C. C., Andersson, B., and Wold A. E. (2005). Gram-positive and Gram-negative bacteria elicit different patterns of pro-inflammatory cytokines in human monocytes. Cytokine 30, 311-318.

Hether, N. W., and Jackson, L. L. (1983). Lipoteichoic acid from Listeria monocytogenes. J. Bacteriol. 156, 809-817.

Hill, A. B. (1965). The environment and disease: association or causation? Proc. R. Soc. Med. 58, 295-300.

Hoffmann, S., Peterbauer, A., Schindler, S., Fennrich, S., Poole, S., Mistry, Y., Montag-Lessing, T., Spreitzer, I., Löschner, B., van Aalderen, M., Bos, R., Gommer, M., Nibbeling, R., Werner-Felmayer, G., Loitzl, P., Jungi, T., Brcic, M., Brügger, P., Frey, E., Bowe, G., Casado, J. Coecke, S., de Lange, J., Mogster, B., Naess, L. M., Aaberge, I. S., Wendel, A., and Hartung, T. (2005). International validation of novel pyrogen tests based on human monocytoid cells. J. Immunol. Methods 298 161-173.
Huff, E., Cole, R. M., and Theodore, T. S. (1974). Lipoteichoic acid localization in mesosomal vesicles of Staphylococcus aureus. J. Bacteriol. 120, 273-281.

Hummell, D. S., Swift, A. J., Tomasz, A., and Winkelstein, J. A. (1985). Activation of the alternative complement pathway by pneumococcal lipoteichoic acid. Infect. Immun. 47, 384-387.

Into, T., Kanno, Y., Dohkan, J., Nakashima, M., Inomata, M., Shibata, K., Lowenstein, C. J., and Matsushita, K.(2007). Pathogen recognition by Toll-like receptor 2 activates Weibel-Palade body exocytosis in human aortic endothelial cells. $J$. Biol. Chem. 282, 8134-8141.

Iwasaki, H., Araki, Y., Ito, E., Nagaoka, M., and Yokokura, T. (1990). Structure of macroamphiphiles from several Bifidobacterium strains. J. Bacteriol. 172, 845-852.

Iwasaki, H., Shimada, A., and Ito, E. (1986). Comparative studies of lipoteichoic acids from several Bacillus strains. J. Bacteriol. 167, 508-516.

Iwasaki, H., Shimada, A., Yokoyama, K., and Ito, E. (1989). Structure and glycosylation of lipoteichoic acids in Bacillus strains. J. Bacteriol. 171, 424-429.

Jacinto, R., Hartung, T., McCall, C., and Li, L. (2002). Lipopolysaccharideand lipoteichoic acid-induced tolerance and cross-tolerance: distinct alterations in IL-1 receptorassociated kinase 1. J. Immunol. 168, 6136-6141.

Joseph, R., and Shockman, G. D. (1975). Cellular localization of lipoteichoic acid in Streptococcus faecalis. J. Bacteriol. 122, 1375-1386.

Kim, H., Yang, J., Woo, S., Kim, S. K., Yun, C. H., Kim, K. K., and Han, S. H. (2007a). Lipoteichoic acid and muramyl dipeptide synergistically induce maturation of human dendritic cells and concurrent expression of proinflammatory cytokines. J. Leukoc. Biol. 81, 983-989.

Kim, H. G., Gim, M. G., Kim, J. Y., Hwang, H. J., Ham, M. S., Lee, J. M., Hartung, T., Park, J. W., Han, S. H., and Chung, D. K. (2007b). Lipoteichoic acid from Lactobacillus plantarum elicits both the production of interleukin-23p19 and suppression of pathogen-mediated interleukin10 in THP-1 cells. FEMS Immunol. Med. Microbiol. 49, 205-214.

Kim, H. G., Kim, N. R., Gim, M. G., Lee, J. M., Lee, S. Y., Ko, M. Y., Kim, J. Y., Han, S. H., and Chung, D. K. (2008). Lipoteichoic acid isolated from Lactobacillus plantarum 
inhibits lipopolysaccharide-induced TNF-alpha production in THP-1 cells and endotoxin shock in mice. J. Immunol. 180, 2553-2561.

Kim, H. J., Jo, E. K., Park, J. K., Lim, J. H., Min, D., and Paik, T. H. (1999). Isolation and partial characterisation of the Triton X-100 solubilised protein antigen from Mycobacterium tuberculosis. J. Med. Microbiol. 48, 585-591.

Kim, J. H., Seo, H., Han, S. H., Lin, J., Park, M. K., Sorensen, U. B., and Nahm, M. H. (2005). Monoacyl lipoteichoic acid from pneumococci stimulates human cells but not mouse cells. Infect. Immun. 73, 834-840.

Kimbrell, M., Warshakoon, H., Cromer, J., Malladi, S., Hood, J. D., Balakrishna, R., Scholdberg, T. A., and David, S. A. (2008). Comparison of the immunostimulatory and proinflammatory activities of candidate Gram-positive endotoxins, lipoteichoic acid, peptidoglycan, and lipopeptides, in murine and human cells. Immunol. Lett. 118, 132-141.

Knox, K. W., and Wicken, A. J. (1972). Serological studies on the teichoic acids of Lactobacillus plantarum. Infect. Immun. 6, 43-49.

Kochanowski, B., Fischer, W., IidaTanaka, N., and Ishizuka, I. (1993). Isomalto-oligosaccharidecontaining lipoteichoic acid of Streptococcus sanguis. Basic structure. Eur. J. Biochem. 214, 747-755.

Kolb-Maurer, A., Kammerer, U., Maurer, M., Gentschev, I., Bröcker, E. B., Rieckmann, P., and Kämpgen, E. (2003). Production of IL-12 and IL18 in human dendritic cells upon infection by Listeria monocytogenes. FEMS Immunol. Med. Microbiol. 35, 255-262.

Kumar, H., Kawai, T., and Akira, S. (2009). Toll-like receptors and innate immunity. Biochem. Biophys. Res. Commun. 388, 621-625.

Labischinski, H., Naumann, D., and Fischer, W. (1991). Small and medium-angle X-ray analysis of bacterial lipoteichoic acid phase structure. Eur. J. Biochem. 202, 1269-1274.

Langer, M., Malykhin, A., Maeda, K., Chakrabarty, K., Williamson, K. S., Feasley, C. L., West, C. M., Metcalf, J. P., and Coggeshall, K. M. (2008). Bacillus anthracis peptidoglycan stimulates an inflammatory response in monocytes through the p38 mitogen-activated protein kinase pathway. PLOS ONE 3, e3706. doi:10.1371/journal.pone.0003706
Lee, S. C., Kim, S. H., Park, I. H., Chung, S. Y., and Choi, Y. L. (2007). Isolation and structural analysis of bamylocin A, novel lipopeptide from Bacillus amyloliquefaciens LP03 having antagonistic and crude oilemulsifying activity. Arch. Microbiol. 188, 307-312.

Lehner, M. D., Morath, S., Michelsen, K. S., Schumann, R. R., and Hartung, T. (2001). Induction of crosstolerance by LPS and highly purified lipoteichoic acid via different Toll like receptors independent of paracrine mediators. J. Immunol. 165, 5161-5167.

Leopold, K., and Fischer, W. (1991). Separation of the poly(glycerophosphate) lipoteichoic acids of Enterococcus faecalis Kiel 27738, Enterococcus hirae ATCC 9790 and Leuconostoc mesenteroides DSM 20343 into molecular species by affinity chromatography on concanavalin A. Eur. J. Biochem. 196, 475-482.

Leopold, K., and Fischer, W. (1992). Hydrophobic interaction chromatography fractionates lipoteichoic acid according to the size of the hydrophilic chain: a comparative study with anion-exchange and affinity chromatography for suitability in species analysis. Anal. Biochem. 201, 350-355.

Levels, J., Abraham, P., van Barreveld, E., Meijers, J., and van Deventer, S. (2003). Distribution and kinetics of lipoprotein-bound lipoteichoic acid. Infect. Immun. 71, 3280-3284.

Li, H., Nooh, M. M., Kotb, M., and Re, F. (2008). Commercial peptidoglycan preparations are contaminated with superantigen-like activity that stimulates IL-17 production. J. Leukoc. Biol. 83, 409-418.

Liu, X. Y., Yang, S. Z., and Mu, B. Z. (2008). Isolation and characterization of a C12-lipopeptide produced by Bacillus subtilis HSO 121. J. Pept. Sci. 14, 864-875.

Mancuso, G., Tomasello, F., Ofek, I., and Teti, G. (1994). Anti-lipoteichoic acid antibodies enhance release of cytokines by monocytes sensitized with lipoteichoic acid. Infect. Immun. 62, 1470-1473.

Martinez-Martinez, L., Timmerman, C. P., Fleer, A., and Verhoef, J. (1993). Chemiluminescence of human polymorphonuclear leucocytes after stimulation with whole cells and cell-wall components of Staphylococcus epidermidis. J. Med. Microbiol. 39, 196-203.

Maurer, J. J., and Mattingly, S. J. (1991). Molecular analysis of lipoteichoic acid from Streptococcus agalactiae. J. Bacteriol. 173, 487-494.

McCurdy, J. D., Olynych, T. J., Maher, L. H., and Marshall, J. S. (2003). Cutting edge: distinct Toll-like receptor 2 activators selectively induce different classes of mediator production from human mast cells. J. Immunol. 170, 1625-1629.

Meron-Sudai, S., Matityahou, A., Keisari, Y., Cox, K., Hasty, D., and Ofek, I. (2008). Lipoteichoic acid synergizes with glycosphingolipids to potently stimulate secretion of interleukin6 from human blood cells. Clin. Vaccine Immunol. 15, 1309-1315.

Meyer, P. D., and Wouters, J. T. (1987) Lipoteichoic acid from Bacillus subtilis subsp. niger WM: isolation and effects on cell wall autolysis and turnover. J. Bacteriol. 169, 973-980.

Morath, S., Geyer, A., and Hartung, T. (2001). Structure-function relationship of cytokine induction by lipoteichoic acid from Staphylococcus aureus. J. Exp. Med. 193, 393-397.

Morath, S., Geyer, A., Spreitzer, I., Hermann, C., and Hartung, T. (2002a). Structural decomposition and heterogeneity of commercial lipoteichoic acid preparations. Infect. Immun. 70, 938-944.

Morath, S., Stadelmaier, A., Geyer, A., Schmidt, R., and Hartung, T. (2002b). Synthetic lipoteichoic acid from Staphylococcus aureus is a potent stimulus of cytokine release. J. Exp. Med. 195, 1635-1640.

Mueller, M., Stamme, C., Draing, C., Hartung, T., Seydel, U., and Schromm, A. (2006). Cell activation of human macrophages by lipoteichoic acid is strongly attenuated by lipopolysaccharide-binding protein. J. Biol. Chem. 281, 31448-31456.

Nakano, M., and Fischer, W. (1978). Trihexosyldiacylglycerol and acyltrihexosyldiacylglycerol as lipid anchors of the lipoteichoic acid of Lactobacillus casei DSM 20021. Hoppe-Seyler's Z. Physiol. Chem. 359, 1-11.

Natsuka, M., Uehara, A., Yang, S., Echigo, S., and Takada, H. (2008). A polymer-type water-soluble peptidoglycan exhibited both Toll-like receptor 2- and NOD2-agonistic activities, resulting in synergistic activation of human monocytic cells. Innate Immun. 14, 298-308.

Navarre, W. W., and Schneewind, O. (1999). Surface proteins of grampositive bacteria and mechanisms of their targeting to the cell wall envelope. Microbiol. Mol. Biol. Rev. 63, 174-229.

Nealon, T. J., and Mattingly, S. J. (1983). Association of elevated levels of cellular lipoteichoic acids of group B streptococci with human neonatal disease. Infect. Immun. 39, 1243-1251.

Neugebauer, E. A., and Holaday, J. W. (1993). Handbook of Mediators in Septic Shock, 1st Edn. Boca Raton, FL: CRC-Press, 1-608.

Neugebauer, E. A., and Lorenz, W. (1989). Meta-analysis: from classical review to a new refined methodology. Theor. Surg. 4, 79-85.

Oettinger, W. (1989). Meta-analysis: only a part of the story on mediators in septic shock. Theor. Surg. 4, 86-88.

Ohshima, Y., Beuth, J., Yassin, A., Ko, H. L., and Pulverer, G. (1988) Stimulation of human monocyte chemiluminescence by staphylococcal lipoteichoic acid. Med. Microbiol. Immunol. 177, 115-121.

Op den Camp, H. J., Veerkamp, J. H., Oosterhof, A., and Van Halbeek, H. (1984). Structure of the lipoteichoic acids from Bifidobacterium bifidum spp. pennsylvanicum. Biochim. Biophys. Acta 795, 301-313.

Owen, P., and Salton, M. R. (1975). Isolation and characterization of a mannan from mesosomal membrane vesicles of Micrococcus lysodeikticus. Biochim. Biophys. Acta 406, 214-234.

Parker, L. C., Whyte, M. K., Vogel, S. N., Dower, S. K., and Sabroe, I. (2004). Toll-like receptor (TLR)2 and TLR4 agonists regulate CCR expression in human monocytic cells. J. Immunol. 172, 4977-4986.

Perea Velez, M., Verhoeven, T. L., Draing, C., Von Aulock, S., Pfitzenmaier, M., Geyer, A., Lambrichts, I., Grangette, C., Pot, B., Vanderleyden, J., and De Keersmaecker, S. C. (2007). Functional analysis of Dalanylation of lipoteichoic acid in the probiotic strain Lactobacillus rhamnosus GG. Appl. Environ. Microbiol. 73, 3595-3604.

Plitnick, L. M., Jordan, R. A., Banas, J. A., Jelley-Gibbs, D. M., Walsh, M. C., Preissler, M. T., and Gosselin, E. J. (2001). Lipoteichoic acid inhibits interleukin-2 (IL-2) function by direct binding to IL-2. Clin. Diagn. Lab. Immunol. 8, 972-979.

Pollack, J. H., Ntamere, A. S., and Neuhaus, F. C. (1992). D-alanyllipoteichoic acid in Lactobacillus casei: secretion of vesicles in response to benzylpenicillin. J. Gen. Microbiol. 138, 849-859.

Rahman, O., Cummings, S. P., and Sutcliffe, I. C. (2009a). Phenotypic variation in Streptomyces sp. DSM 40537, a lipoteichoic acid producing 
actinomycete. Lett. Appl. Microbiol. 48, 226-229.

Rahman, O., Pfitzenmaier, M., Pester, O., Morath, S., Cummings, S. P., Hartung, T., Sutcliffe, I. C. (2009b). Macroamphiphilic components of thermophilic actinomycetes: identification of lipoteichoic acid in Thermobifida fusca. J. Bacteriol. 191, 152-160.

Raisanen, L., Schubert, K., Jaakonsaari, T., and Alatossava, T. (2004). Characterization of lipoteichoic acids as Lactobacillus delbrueckii phage receptor components. J. Bacteriol. 186, 5529-5532.

Rockel, C., Hartung, T., and Hermann, C. (2011). Different S. aureus whole bacteria mutated in putative pro-inflammatory membrane components have similar cytokineinducing activity. Immunobiology 216, 316-321.

Rose, R. K., and Hogg, S. D. (1995). Competitive binding of calcium and magnesium to streptococcal lipoteichoic acid. Biochim. Biophys. Acta 1245, 94-98.

Ruhland, G. J., and Fiedler, F. (1990). Occurrence and structure of lipoteichoic acids in the genus Staphylococcus. Arch. Microbiol. 154, 375-379.

Rusch, D. B., Halpern, A. L., Sutton, G., Heidelberg, K. B., Williamson, S., Yooseph, S., Wu, D., Eisen, J. A., Hoffman, J. M., Remington, K., Beeson, K., Tran, B., Smith, H., BadenTillson, H., Stewart, C., Thorpe, J., Freeman, J., Andrews-Pfannkoch, C., Venter, J. E., Li, K., Kravitz, S., Heidelberg, J. F., Utterback, T., Rogers, Y. H., Falcón, L. I., Souza, V., Bonilla-Rosso, G., Eguiarte, L. E., Karl, D. M., Sathyendranath, S., Platt, T., Bermingham, E., Gallardo, V., Tamayo-Castillo, G., Ferrari, M. R., Strausberg, R. L., Nealson, K., Friedman, R., Frazier, M., and Venter, J. C. (2007). The sorcerer II global ocean sampling expedition: northwest Atlantic through eastern tropical Pacific. PLoS Biol. 5:e77. doi:10.1371/journal.pbio.0050077

Ryu, Y. H., Baik, J. E., Yang, J. S., Kang, S. S., Im, J., Yun, C. H., Kim, D. W., Lee, K., Chung, D. K., Ju, H. R., and Han, S. H. (2009). Differential immunostimulatory effects of Gram-positive bacteria due to their lipoteichoic acids. Int. Immunopharmacol. 9, 127-133.

Schindler, S., Spreitzer, I., Loschner, B., Hoffmann, S., Hennes, K., Halder, M., Brügger, P., Frey, E., Hartung, T., and Montag, T. (2006). International validation of pyrogen tests based on cryopreserved human primary blood cells. J. Immunol. Methods 316, 42-51.

Schindler, S., von Aulock, S., Daneshian, M., and Hartung, T. (2009). Development, validation and applications of the monocyte activation test for pyrogens based on human whole blood. ALTEX 26, 265-277.

Schroder, N., Morath, S., Alexander, C., Hamann, L., Hartung, T., Zähringer, U., Göbel, U. B., Weber, J. R., and Schumann, R. R. (2003). Lipoteichoic acid (LTA) of S. pneumoniae and S. aureus activates immune cells via Toll-like receptor (TLR)2, LPS binding protein (LBP) and CD14 while TLR-4 and MD-2 are not involved. J. Biol. Chem. 278, 15587-15594.

Schroder, N. W., Eckert, J., Stubs, G., and Schumann, R. R. (2008). Immune responses induced by spirochetal outer membrane lipoproteins and glycolipids. Immunobiology 213, 329-340.

Schroder, N. W., Heine, H., Alexander, C., Manukyan, M., Eckert, J., Hamann, L., Göbel, U. B., and Schumann, R. R. (2004). Lipopolysaccharide binding protein binds to triacylated and diacylated lipopeptides and mediates innate immune responses. J. Immunol. 173, 2683-2691.

Schromm, A., Howe, J., Ulmer, A., Wiesmüller, K. H., Seyberth, T., Jung, G., Rössle, M., Koch, M. H., Gutsmann, T., and Brandenburg, K. (2007). Physicochemical and biological analysis of synthetic bacterial lipopeptides: validity of the concept of endotoxic conformation. J. Biol. Chem. 282, 11030-11037.

Schurek, J., and Fischer, W. (1989). Distribution analyses of chain substituents of lipoteichoic acids by chemical degradation. Eur. J. Biochem. 186, 649-655.

Schwandner, R., Dziarski, R., Wesche, H., Rothe, M., and Kirschning, C. J. (1999). Peptidoglycan- and lipoteichoic acid-induced cell activation is mediated by Toll-like receptor 2 . J. Biol. Chem. 274, 17406-17409.

Sherman, L. A., and Savage, D. C. (1986). Lipoteichoic acids in Lactobacillus strains that colonize the mouse gastric epithelium. Appl. Environ. Microbiol. 52, 302-304.

Shockley, R. K., and Kleinman, R. (1982). Bacteria-immune system interactions. III. Isolation of a Bacillus globigii cell wall component involved in binding to human lymphocytes. Cell. Immunol. 66, 202-205.

Sieling, P., Chung, W., Duong, B., Godowski, P., and Modlin, R. (2003).
Toll-like receptor 2 ligands as adjuvants for human Th1 responses. $J$ Immunol. 170, 194-200.

Sijtsma, L., Wouters, J. T., and Hellingwerf, K. J. (1990). Isolation and characterization of lipoteichoic acid, a cell envelope component involved in preventing phage adsorption, from Lactococcus lactis subsp. Cremoris SK110. J. Bacteriol. 172, 7126-7130.

Silvestri, L. J., Craig, R. A., Ingram, L. O. Hoffmann, E. M., and Bleiweis, A. S. (1978). Purification of lipoteichoic acids by using phosphatidyl choline vesicles. Infect. Immun. 22, 107-118.

Stadelmaier, A., Figueroa-Perez, I. Deininger, S., von Aulock, S., Hartung, T., and Schmidt, R. R. (2006). A Staphylococcus aureus lipoteichoic acid (LTA) derived structural variant with two diacylglycerol residues. Bioorg. Med. Chem. 14, 6239-6254.

Stewart, G. R., Wilkinson, K. A., Newton, S. M., Sullivan, S. M., Neyrolles, O., Wain, J. R., Patel, J., Pool, K. L., Young, D. B., and Wilkinson, R. J. (2005). Effect of deletion or overexpression of the 19-kilodalton lipoprotein $\operatorname{Rv} 3763$ on the innate response to Mycobacterium tuberculosis. Infect. Immun. 73, 6831-6837.

Stoll, H., Dengjel, J., Nerz, C., and Gotz, F. (2005). Staphylococcus aureus deficient in lipidation of prelipoproteins is attenuated in growth and immune activation. Infect. Immun. 73, 2411-2423.

Stuertz, K., Merx, I., Eiffert, H. Schmutzhard, E., Mader, M., and Nau, R. (1998). Enzyme immunoassay detecting teichoic and lipoteichoic acids versus cerebrospinal fluid culture and latex agglutination for diagnosis of Streptococcus pneumoniae meningitis. J. Clin. Microbiol. 36, 2346-2348.

Suda, Y., Tochio, H., Kawano, K., Takada, H., Yoshida, T., Kotani, S., and Kusumoto, S. (1995). Cytokine-inducing glycolipids in the lipoteichoic acid fraction from Enterococcus hirae ATCC 9790. FEMS Immunol. Med. Microbiol. 12, 97-112.

Sutcliffe, I. C., and Shaw, N. (1991) Atypical lipoteichoic acids of grampositive bacteria. J. Bacteriol. 173, 7065-7069.

Takeuchi, O., Hoshino, K., Kawai, T., Sanjo, H., Takada, H., Ogawa, T., Takeda, K., and Akira, S.(1999). Differential roles of TLR2 and TLR4 in recognition of gramnegative and gram-positive bacterial cell wall components. Immunity 11, 443-451.

Talreja, J., Kabir, M., Filla, M., Stechschulte, D., and Dileepan, K.
(2004). Histamine induces Toll-like receptor 2 and 4 expression in endothelial cells and enhances sensitivity to Gram-positive and Gram-negative bacterial cell wall components. Immunology 113, 224-233.

Tanaka, M., Hori, Y., Ueda, H., Ezaki, M., Goto, T., Hashimoto, M., and Okuhara, M. (1993). WS1279, a novel lipopeptide isolated from Streptomyces willmorei. Fermentation, isolation and physicochemical properties. J. Antibiot. 46, 858-860.

Teti, G., Chiofalo, M. S., Tomasello, F., Fava, C., and Mastroeni, P. (1987). Mediation of Staphylococcus saprophyticus adherence to uroepithelial cells by lipoteichoic acid. Infect. Immun. 55, 839-842.

Theilacker, C., Kaczynski, Z., Kropec, A., Fabretti, F., Sange, T., Holst, O. and Huebner, J. (2006). Opsonic antibodies to Enterococcus faecalis strain 12030 are directed against lipoteichoic acid. Infect. Immun. 74, 5703-5712.

Traub, S., von Aulock, S., Hartung, T. and Hermann, C. (2006). MDP and other muropeptides - direct and synergistic effects on the immune system. J. Endotoxin Res. 12, 69-85.

Travassos, L., Girardin, S., Philpott, D., Blanot, D., Nahori, M. A., Werts, C., and Boneca, I. G. (2004). Tolllike receptor 2-dependent bacterial sensing does not occur via peptidoglycan recognition. EMBO Rep. 5, 1000-1006.

Triantafilou, M., Brandenburg, K., Gutsmann, T., Seydel, U., and Triantafilou, K. (2002). Innate recognition of bacteria: engagement of multiple receptors. Crit. Rev. Immunol. 22, 251-268.

Uchikawa, K., Sekikawa, I., and Azuma, I. (1986). Structural studies on lipoteichoic acids from four Listeria strains. J. Bacteriol. 168, 115-122.

Uehara, A., Fujimoto, Y., Kawasaki, A., Kusumoto, S., Fukase, K., and Takada, H. (2006). Mesodiaminopimelic acid and mesolanthionine, amino acids specific to bacterial peptidoglycans, activate human epithelial cells through NOD1. J. Immunol. 177, 1796-1804.

Uehara, A., Sugawara, S., and Takada, H. (2002). Priming of human oral epithelial cells by interferon$\gamma$ to secrete cytokines in response to lipopolysaccharides, lipoteichoic acids and peptidoglycans. J. Med. Microbiol. 51, 626-634.

Uehara, A., Yang, S., Fujimoto, Y., Fukase, K., Kusumoto, S., Shibata, K., Sugawara, S., and Takada, H. 
(2005). Muramyldipeptide and diaminopimelic acid-containing desmuramylpeptides in combination with chemically synthesized Toll-like receptor agonists synergistically induced production of interleukin-8 in a NOD2and NOD1-dependent manner, respectively, in human monocytic cells in culture. Cell. Microbiol. 7, 53-61.

Vollmer, W., and Holtje, J. V. (2004). The architecture of the murein (peptidoglycan) in gram-negative bacteria: vertical scaffold or horizontal layer(s)? J. Bacteriol. 186, 5978-5987.

von Aulock, S., Hartung, T., and Hermann, C. (2007). Comment on "Not lipoteichoic acid but lipoproteins appear to be the dominant immunobiologically active compounds in Staphylococcus aureus." J. Immunol. 178, 2610.

Wang, J., Doyle, M., Manning, B., Di Wu, Q., Blankson, S., and Redmond, H. (2002). Induction of bacterial lipoprotein tolerance is associated with suppression of Toll-like receptor 2 expression. J. Biol. Chem. 277, 36068-36075.

Wang, J. E., Jorgensen, P. F., Almlof, M., Thiemermann, C., Foster, S. J., Aasen, A. O., and Solberg, R. (2000). Peptidoglycan and lipoteichoic acid from Staphylococcus aureus induce tumor necrosis factor alpha, interleukin 6 (IL-6), and IL-10 production in both $\mathrm{T}$ cells and monocytes in a human whole blood model. Infect. Immun. 68, 3965-3970.

Wicken, A. J., Gibbens, J. W., and Knox, K. W. (1973). Comparative studies on the isolation of membrane lipoteichoic acid from Lactobacillus fermenti. J. Bacteriol. 113, 365-372.

Wicken, A. J., and Knox, K. W. (1975). Characterization of group N streptococcus lipoteichoic acid. Infect. Immun. 11, 973-981.

Wilkinson, K. A., Newton, S. M., Stewart, G. R., Martineau, A. R., Patel, J., Sullivan, S. M., Herrmann, J. L., Neyrolles, O., Young, D. B., and Wilkinson, R. J. (2009). Genetic determination of the effect of posttranslational modification on the innate immune response to the 19 $\mathrm{kDa}$ lipoprotein of Mycobacterium tuberculosis. BMC Microbiol. 9, 93. doi:10.1186/1471-2180-9-93

Wolfert, M., Murray, T., Boons, G., and Moore, J. (2002). The origin of the synergistic effect of muramyl dipeptide with endotoxin and peptidoglycan. J. Biol. Chem 277, 39179-39186.

Wu, L., Feng, B. S., He, S. H., Zheng, P. Y., Croitoru, K., and Yang, P. C. (2007). Bacterial peptidoglycan breaks down intestinal tolerance via mast cell activation: the role of TLR2 and NOD2. Immunol. Cell Biol. 85, 538-545.

Wu, Y., Qiu, H., Zeng, Y., You, X., Deng, Z., Yu, M., and Zhu, C. (2008). Mycoplasma genitalium lipoproteins induce human monocytic cell expression of proinflammatory cytokines and apoptosis by activating nuclear factor kappaB. Mediators Inflamm. 2008, 195427.
Conflict of Interest Statement: The authors declare that the research was conducted in the absence of any commercial or financial relationships that could be construed as a potential conflict of interest.

Received: 13 December 2011; accepted: 17 March 2012; published online: 17 April 2012.

Citation: Rockel $C$ and Hartung $T$ (2012) Systematic review of membrane components of Gram-positive bacteria responsible as pyrogens for inducing human monocyte/macrophage cytokine release. Front. Pharmacol. 3:56. doi: 10.3389/fphar.2012.00056

This article was submitted to Frontiers in Predictive Toxicity, a specialty of Frontiers in Pharmacology.

Copyright (C) 2012 Rockel and Hartung. This is an open-access article distributed under the terms of the Creative Commons Attribution Non Commercial License, which permits non-commercial use, distribution, and reproduction in other forums, provided the original authors and source are credited. 